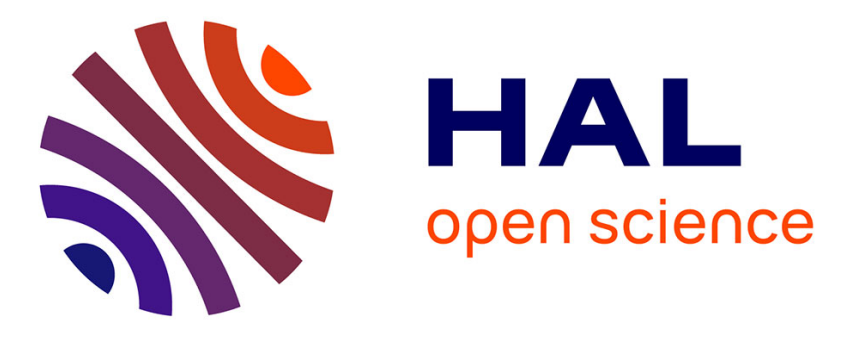

\title{
Population genetic structure of blue-spotted maskray Neotrygon kuhlii and two other Indo-West Pacific stingray species (Myliobatiformes: Dasyatidae), inferred from size-polymorphic intron markers
}

\author{
Philippe Borsa, Irma S. Arlyza, Martin Laporte, Patrick Berrebi
}

\section{To cite this version:}

Philippe Borsa, Irma S. Arlyza, Martin Laporte, Patrick Berrebi. Population genetic structure of bluespotted maskray Neotrygon kuhlii and two other Indo-West Pacific stingray species (Myliobatiformes: Dasyatidae), inferred from size-polymorphic intron markers. Journal of Experimental Marine Biology and Ecology, 2012, 438, pp.32-40. 10.1016/j.jembe.2012.09.010 . ird-00747306

\author{
HAL Id: ird-00747306 \\ https://hal.ird.fr/ird-00747306
}

Submitted on 31 Oct 2012

HAL is a multi-disciplinary open access archive for the deposit and dissemination of scientific research documents, whether they are published or not. The documents may come from teaching and research institutions in France or abroad, or from public or private research centers.
L'archive ouverte pluridisciplinaire HAL, est destinée au dépôt et à la diffusion de documents scientifiques de niveau recherche, publiés ou non, émanant des établissements d'enseignement et de recherche français ou étrangers, des laboratoires publics ou privés. 
To be cited as:

Borsa P., Arlyza I.S., Laporte M., Berrebi P. (2012) Population genetic structure of blue-spotted maskray Neotrygon kublii and two other Indo-West Pacific stingray species (Myliobatiformes: Dasyatidae), inferred from size-polymorphic intron markers. J. Exp. Mar. Biol. Ecol. 438, 32-40. [doi:10.1016/j.jembe.2012.09.010]

Population genetic structure of blue-spotted maskray Neotrygon kuhlii and two other Indo-West Pacific stingray species (Myliobatiformes: Dasyatidae), inferred from size-polymorphic intron markers

Philippe Borsa a, ${ }^{\text {, }}$ Irma S. Arlyza ${ }^{\text {b }}$, Martin Laporte c,d, Patrick Berrebi c

a Institut de recherche pour le développement (IRD), UR 227 «Biocomplexité des écosystèmes récifaux », Montpellier, France

b Lembaga Ilmu Pengetahuan Indonesia (LIPI), Pusat Penelitian Oseanografi (P2O), Ancol, Jakarta, Indonesia

c Institut des sciences de l'évolution à Montpellier (ISE-M), UMR 5554 UM2-CNRS-IRD, Université Montpellier 2, CC065, Place E. Bataillon, 34095 Montpellier cedex 5, France

d Centre de recherche sur les bassins versants - écosystèmes aquatiques, Université du Québec à TroisRivières, Trois-Rivières, Canada

${ }^{*}$ Corresponding author, present address: Indonesian Biodiversity Research Center, Universitas Udayana, J1 Sesetan Gang Markisa 6, Denpasar, Indonesia E-mail: philippe.borsa@ird.fr (P. Borsa) 


\section{ABSTRACT}

Exon-primed, intron crossing DNA markers (EPICs) were screened for Mendelian-like allele size polymorphisms in three stingray species (Himantura gerrardi, Neotrygon kublii and Taeniura lymna) from the central Indo-West Pacific, where they are commercially exploited. Four to 7 size-polymorphic intron loci were selected in a species, and were subsequently tested as genetic markers of stock structure. Sharp genetic differentiation was observed between populations within each species across the Indo-Malay-Papua archipelago (Weir and Cockerham's $\wedge^{\wedge} \theta$-values reaching $0.153-0.557$ over a few thousand $\mathrm{km}$ ). A trend of increasing genetic differentiation with increasing geographic distance was apparent in N. kublii, in which populations distant by $3,000 \mathrm{~km}$ were differentiated by an estimated ${ }^{\wedge} \theta \sim 0.375$. This value was an order of magnitude higher than usually reported in coastal benthic teleost fishes and indicates strong sub-population structure. This is likely, at least partly, a consequence of the sedentary benthic habits of $N$. kublii at all life stages. Because replenishment of overexploited populations of $N$. kublii and two other stingray species from the central Indo-West Pacific is unlikely at ecological timescales, management should be planned at the local geographic scale.

Keywords: Himantura gerrardi; Taeniura lymna; population genetic structure; fishery; conservation; Indo-MalayPapua archipelago

\section{Introduction}

One of the problems hampering the proper management of commercially exploitable marine species is the trade-off between the effort necessary for the acquisition of scientifically sound information and the increasing pace at which these resources rarefy. This is particularly true for developing nations in the central Indo-West Pacific region, where marine species richness is highest (Briggs, 2005; Bellwood and Meyer, 2009), human pressure is strong (Sadovy, 2005), management is poor (Pauly, 1994), and science is weaker than in other regions in the Indo-Pacific (Haustein et al., 2011; Meijaard, 2011). The low fecundity and slow maturation of sharks and rays (elasmobranchs), in particular, make them highly vulnerable to overfishing. There is increasing concern over their exploitation in Indonesia, the most populated country of the central Indo-West Pacific (Blaber et al., 2009; White and Kyne, 2010). However, little effort for management and conservation has been made thus far (Blaber et al., 2009; White and Kyne, 2010). If unsustainable exploitation is allowed to continue unmonitored and unregulated, it will cause the depletion of stocks, erode genetic diversity, and eventually lead to the extinction of many shark and ray species in this region.

Among the pre-requisites for sound fishery management is the identification of stocks, a goal that can be reached by assessing the geographic structure of populations using genetic markers (Shaklee and Bentzen, 1998; Begg et al., 1999; Ward, 2000). Assessing geographic structure in sharks has been hampered due to low variability of allozyme markers and in mitochondrial DNA (Heist et al., 2003). Recent studies of population genetic structure in elasmobranchs have relied on the hypervariable mitochondrial control region sequences and on microsatellite polymorphisms (Chevolot et al., 2008; Schluessel et al., 2010; Le Port and Lavery, 2012; Portnoy and Heist, 2012). The degree of genetic population subdivision in rays and skates still remains under-investigated (Schluessel et al., 2010) although there is an urgent need for such information for commercially targeted species in the central Indo-West Pacific. 
The initial aim of the present study was to select size-polymorphic nuclear markers in several stingray species (Elasmobranchia: Dasyatidae). Exon-primed, PCR-amplified introns (EPIC) were chosen because they can provide such markers of population genetic structure with minimal investment. For instance, a single pair of universal EPIC primers simultaneously allows the amplification of up to several introns in a gene family (Chow and Takeyama, 1998; Hassan et al., 2002; Atarhouch et al., 2003). Compared to microsatellites, another advantage of EPIC markers is that null alleles are less likely, since EPIC primers are anchored in conserved regions. Last, an undesirable property of microsatellites is allele-size homoplasy (Garza and Freimer, 1996; Ellegren, 2004), which is unlikely to occur with EPIC markers when mutations that affect allele size are caused by indels (Creer, 2007). We screened for size polymorphism a number of primer pairs that are known to amplify EPICs in teleost fishes. The rationale for expecting crossamplification with stingrays comes from the fact that exons of a number of EPIC genes are conserved across orders in Metazoans (e.g. Palumbi et al. 1991; Chenuil et al., 2010). Three stingray species among the most common at fish landing sites in the Indo-Malay-Papua archipelago in the central Indo-West Pacific (White and Dharmadi, 2007) were chosen as test species: the sharpnose stingray, Himantura gerrardi (Gray, 1851), the blue-spotted maskray, Neotrygon kublii (Müller and Henle, 1841) and the ribbontail stingray, Taeniura lymna (Forsskål, 1775). Whether the selected intron markers are suitable for assessing population genetic structure was further investigated in N. kublii, on the basis of an adequate geographic sampling that extended from the Indian Ocean Java coast to the Molucca Sea. Prior to the present survey, cytochromeoxidase I gene sequences from a barcoding survey of Indo-Australian chondrichthyans have shown strong genetic differences within H. gerrardi and N. kublii (Ward et al., 2008), but no firm evidence that both actually harbour cryptic species within the Indo-Malay archipelago. The present survey may help address this issue because nuclear markers allow the detection of reproductive isolation when cryptic species co-occur sympatrically.

\section{Materials and methods}

\subsection{Sampling}

Three stingray species, Himantura gerrardi, Neotrygon kublii and Taeniura lymna were sampled from 3-6 landing sites across the Indo-Malay-Papua archipelago (Fig. 1). Sample sizes per species per sampling site ranged from 2 to 40 . A piece of flesh and skin $\left(0.05-0.5 \mathrm{~cm}^{2}\right)$ was dissected at the extremity of the disk using surgical scissors, and immediately preserved in ethanol. Total genomic DNA was extracted using the DNeasy ${ }^{\circledR}$ Tissue Kit (Qiagen GmbH; Hilden, Germany), or using Chelex 100 resin beads (Bio-Rad, Hercules CA) according to Walsh et al. (1991).

\subsection{PCR conditions and selection of markers}

A preliminary series of tests consisted of amplifying by polymerase chain reaction (PCR) the DNA of 2-6 individuals from each of 3 regional samples of each stingray species using 20 EPIC primer pairs available in our laboratory (Supplementary material, Table S1). Those primer pairs that revealed sizepolymorphic loci were then selected. PCRs were carried out in a total volume of $10 \mu \mathrm{L}$, containing $1 \mu \mathrm{L} 10 \mathrm{X}$ Taq buffer (Promega Corporation, Madison WI), $2.5 \mathrm{mM} \mathrm{MgCl}_{2}, 0.2 \mathrm{mM}$ of each dNTP (Invitrogen, San Diego CA), $0.5 \mathrm{mM}$ of each primer (MWG-Biotech, Ebersberg, Germany), the forward primer being fluorescently labelled with either 6-carboxyfluorescein (6-FAM), indodicarbocyanine (Cy5), or 
tetramethylrhodamine (TAMRA), $0.3 \mathrm{U}$ Taq polymerase and $1 \mu \mathrm{L}$ template DNA (at about $150 \mathrm{mg} / \mathrm{ml}$ ). PCRs were run in a Mastercycler thermal cycler (Eppendorf, Hamburg, Germany), where thermo-cycling conditions consisted of initial heating at $94^{\circ} \mathrm{C}$ for $3 \mathrm{~min}$, followed by 35 cycles of heating at $94^{\circ} \mathrm{C}$ for $1 \mathrm{~min}$, annealing at $54^{\circ} \mathrm{C}$ for $1 \mathrm{~min}$, extension at $72^{\circ} \mathrm{C}$ for $1 \mathrm{~min} 20 \mathrm{~s}$, before $10 \mathrm{~min}$ final extension at $72^{\circ} \mathrm{C}$. The PCR products were mixed with $1 \mathrm{vol}$. loading buffer, denatured for 5 min at $95^{\circ} \mathrm{C}$, loaded into vertical $8 \%$ denaturing polyacrylamide gels, and subjected to electrophoresis for $1 \mathrm{hr}$ at $60 \mathrm{~W}$. Fluorescent DNA bands were detected in an FMBIO® II gel scanner (Hitachi Instruments, San José CA).

For each primer pair, a gel exhibited 2 to $>8$ distinct horizontal series of fluorescent bands in a species. Each series of bands was examined for eventual band-size variation and was interpreted as codominant size-polymorphism at a Mendelian locus when the following conditions were met: (1) an individual exhibited either one or two bands; (2) the most commonly encountered bands in two-banded individuals were also observed in at least one single-banded individual; (3) the proportions of single-banded and double-banded individuals in a given sample were reasonably close to those expected for homozygotes and heterozygotes for co-dominant alleles at a Mendelian locus in a panmictic population. Photographs of gels where Mendelian-like intron-length polymorphisms were scored have been presented previously (Borsa et al., 2004; Berrebi et al., 2005; Rohfritsch and Borsa, 2005; Hoareau et al., 2007) and the scan image of a gel illustrating Mendelian-like size polymorphism in T. lymna is presented in Fig. 2. The presumptive loci selected after this first step were then scored for all individuals.

Scoring of individual genotypes was done by eye directly from the gel scan. Sizing of alleles was done with the help of the FMBIO® II gel scan analysis software (Hitachi Instruments) using as a reference a fluorescent DNA ladder (Internal Lane Standard 600; 60-600 bp; Promega Corporation) loaded at regular intervals in the gel.

\subsection{Genetic data analysis}

Estimators of genetic differentiation between populations (Fst) were Weir and Cockerham's (1984) multilocus ${ }^{\wedge} \theta$ and Nei and Chesser's (1983) ${ }^{\wedge} G s t$, the proportion of genetic diversity that resides among subpopulations. Unlike Weir and Cockerham's (1984) $\theta$ which was estimated from genotype frequencies, Gst was estimated from allele frequencies, in order to compare the present results with cases from the literature where only allele frequency data are available. Both $\theta$ and Gst were estimated using GENETIX v 4.02 (Belkhir et al., 2000). The estimated values of $\theta$ were compared to pseudo-distributions generated by random permutations of individuals under GENETIX 4.02 as a test of the null hypothesis $\theta=0$. Wright's Fis was estimated using Weir and Cockerham's (1984) multiallelic ${ }^{\wedge} f$ estimator. The null hypothesis $f=0$ (panmixia) was tested using a similar permutation test under GENETIX 4.02. The probability of occurrence of a parameter value larger than or equal to the observed value was estimated as $P=(n+1) /(N+1)$, where $n$ is the number of pseudo-values larger (or lower for negative $\left.\wedge^{\wedge}\right)$ than or equal to the observed value, and $N$ is the number of random permutations (Sokal and Rohlf, 1995).

The correlation coefficient between genotypes at different loci, R (Garnier-Géré and Dillmann, 1992), was used as a measure of linkage disequilibrium. Random permutations of genotypes at a locus (procedure PERMUTATIONS of GENETIX 4.02) were used to generate a pseudo-distribution of $R$ under the null hypothesis of linkage equilibrium. The correlation coefficient, $R$, and its associated probability under the null hypothesis, $P$, were estimated for each locus pair by GENETIX 4.02. Statistical significance of the estimated values was assessed after correcting for multiple tests (Rice, 1989).

Geographic distance between sampling locations was calculated as the shortest ship distance, using the PATH tool implemented in Google Earth (http://www.google.co.uk/intl/en uk/earth/). The habitat is bi- 
dimensional and the correlation of genetic distance with geographic distance was analyzed according to the two-dimensional model of isolation by distance (IBD) (Rousset, 1997).

The number of populations present in the total sample of $N$. kublii was determined and individuals were assigned to these populations using the model-based program STRUCTURE 2.3.1 (Falush et al., 2007). The Markov chain Monte Carlo algorithm implemented in STRUCTURE was run under the admixture model with correlated allele frequencies for 100,000 steps after 50,000 initial burn-in steps, without any a priori information on an individual's sampling location, to estimate individual admixture proportions and assign individuals to populations. Five independent runs were performed for each number of populations $(K)$ ranging a priori from 2 to 6 to determine the number of populations a posteriori by visually comparing the output diagrams.

IBD and Bayesian structure analyses were not carried out in the two other stingray species, $H$. gerrardi and T. lymna, because of an insufficient geographic coverage and an insufficient number of samples.

\section{Results}

Six primer pairs (Act-2, AldoB5, Cam-3, CK, Gpd2, and RP) (Table 1) each allowed the scoring of at least one presumptive polymorphic locus in at least one of three stingray species surveyed for intron-size polymorphism (Tables 2-4; multilocus genotypes in Supplementary material, Tables S2-S4). The CK primer pair allowed the scoring of a single polymorphic locus in each of the three species. Fig. 2 illustrates Mendelian-like size-polymorphism at locus $C K$ in Taeniura lymna, where all three phenotypes expected for a co-dominant gene at a single locus with two size-alleles are present. All primer pairs of Table 1 have been previously selected to amplify size-polymorphic introns in teleost fishes (Chow and Hazama, 1998; Chow and Takeyama, 1998; Hassan et al., 2002; Atarhouch et al., 2003; Berrebi et al., 2005). Up to 5 polymorphic loci were scored with a single primer pair (e.g. Cam-3; Table 2), which can be due to either amplification of the paralogous intron in several genes of the family (e.g. Friedberg and Rhoads, 2002; Creer, 2007), or perhaps non-specific amplification within a single gene (i.e. several introns of the same gene might have been amplified). For all the other primer pairs tested (Supplementary material, Table S1), either the DNA band patterns were not variable (thus exhibiting sample monomorphism), or they were variable but we failed to interpret them in terms of size polymorphism at Mendelian loci. In a few cases, the amplification was too weak for scoring, the intensity of DNA bands was highly variable across individuals, or a substantial proportion of individuals could not be scored either because of bands that were too weak or because of overlapping bands presumably from other loci.

The suitability of the selected markers to the analysis of population genetic structure was warranted by the general conformity of the genotype frequencies to Hardy-Weinberg expectations, as Weir and Cockerham’s (1984) ^f-estimates were generally not significantly different from 0 (Tables 2-4). There was no evidence of linkage disequilibrium between loci except between Cam-3 slow and $C K$ in N. kublii from the Banda Sea $(R=0.306 ; N=43 ; P<0.001)$. Detailed results of linkage-disequilibrium tests are presented in Supplementary material, Table S5.

The estimate of genetic differentiation between sub-populations was strong in all three species (Table 5), particularly in Neotrygon kublii where a trend of increasing genetic differentiation with increasing geographic distance was apparent (Fig. 3) and populations separated by a distance of 3,000 km were genetically differentiated by an estimated Weir and Cockerham’s (1984) $\wedge^{\wedge} \theta \sim 0.375$ (Fig. 3).

The most likely outcome from Bayesian structure analysis, which was run for $K=2-6$, was with $K=3$. The case where $K=2$ provided less information than $K=3$, and the structure diagrams obtained when $K>3$ 
were increasingly noisy as $K$ increased, yet not more informative than with $K=3$ (see Supplementary material, Table S6 for a comparison of the different structure diagrams). Thus, three genetically distinct populations were identified in N. kublii by Bayesian structure analysis (Fig. 1A; Fig. 4) and confirmed the strong partition inferred from the overall Fst estimate $\left({ }^{\wedge} \theta=0.336\right)$ : one that includes the two samples from the Indian Ocean Java coast; a second that includes the samples from the Bali Strait and the Flores Sea; and a third that was sampled in the Banda Sea only. According to Bayesian structure analysis, the sample from Tomini Bay was close to both the Indian Ocean population and to the Bali Strait / Flores Sea population, although the latter relationship was weaker. Because of the small size of the Tomini Bay sample, its assignment to the Indian Ocean (or Bali Strait / Flores Sea) population should be considered as tentative only. Overall, different oceanic basins seemed to harbour genetically differentiated N. kublii populations.

One of the H. gerrardi samples was of unknown origin. We observed that genetic differentiation between the two geographically close samples from the Sunda Strait and the Java Sea was much lower than genetic differentiation between the two most distant samples (Indian Ocean $v s$. West Papua) with an intermediate value for intermediate distances (e.g. Java Sea vs. Indian Ocean) (Table 5B). Assuming a general trend of increasing genetic differentiation with increasing geographic distance in this species, as in N. kublii, it is possible to infer the approximate geographic origin of the 'Unknown' sample as geographically intermediate between the Indian Ocean and West Papua, and likely closer to the Indian Ocean than to the other sampled locations (Table 5B).

\section{Discussion}

Elasmobranchs suffer indiscriminate exploitation in the Indo-Malay-Papua archipelago (Blaber et al., 2009; White and Kyne, 2010). Given the K-selected life-history characteristics of elasmobranchs, the sustainability of the stocks and even the survival of some of the most vulnerable species are becoming more and more a matter of concern (White and Kyne, 2010). Hence, there is an urgent need to analyze stock structure and provide fisheries and environmental managers with information on population genetic structure, which is relevant to designing management policies.

\subsection{Suitability of intron markers to assess population genetic structure in stingrays}

Screening size polymorphisms using PCR primers known to amplify potentially polymorphic introns in teleost fishes proved an efficient strategy to select a reasonable number of Mendelian-like markers in several stingray species. Here, we showed that these size-polymorphic introns can be employed to assess population geographic structure, which in turn could have useful applications, including the delineation of stocks and the recognition of distinct genetic units of conservation interest.

\subsection{Investigating mechanisms of genetic differentiation}

The levels of population genetic differentiation in Himantura gerrardi, Neotrygon kublii and Taeniura lymna in the Indo-Malay-Papua archipelago (present study), were comparable to the only figure published thus far for another stingray species, Dasyatis brevicaudata. In this species, a significant level of genetic differentiation $\left({ }^{\wedge} F s t=0.160\right.$; mitochondrial DNA control region) has been reported between populations sampled in southwestern Australia and New-Zealand (separated by ca. $5,100 \mathrm{~km}$ ). However, in the same study, the ${ }^{\wedge} F_{s t-}$ value between populations from southwestern Australia and southeastern Australia, separated by $>2,800 \mathrm{~km}$ 
continuous shelf habitat, was only 0.010, whereas the ${ }^{\wedge} F$ st -value across the Tasman Sea (ca. 2,200 km deep sea) was 0.030 (Le Port and Lavery, 2012). In other coastal benthic elasmobranchs, genetic differentiation estimates at nuclear loci (using Wright's Fst or equivalents) ranged from 0.002 to 0.065 over thousands of km (Fig. 5). These average ${ }^{\wedge} F$ st-values may mask locally sharp heterogeneities, as in the Milk shark, where populations from Bali and the northern Great Barrier Reef separated by $3,510 \mathrm{~km}$ differed by ${ }^{\wedge} F_{s t}=0.268$ (Ovenden et al., 2011).

Comparing the levels of genetic differentiation available from the few nuclear-genetic surveys of coastal benthic elasmobranchs, with those from the literature on teleost fishes, four outliers were visible and they included two Dasyatidae from the Indo-Malay-Papua archipelago (H. gerrardi and N. kublii; present study) (Fig. 5; more details in Supplementary material, Table S7). The two other outliers were two teleost fishes sampled across the Indo-West Pacific, the narrow-barred Spanish mackerel Scomberomorus commerson (Fauvelot and Borsa, 2011) and the fourfinger threadfin Eleutheronema tetradactylum (Horne et al., 2011). Since all the other ${ }^{\wedge} F s t$ values for coastal elasmobranchs were positioned within the cluster characterizing most coastal teleosts, there is no evidence from these data, that coastal elasmobranchs have higher geographic composition than teleosts sharing similar habitats. However, the four outliers were sampled in, roughly, the same central Indo-West Pacific region, suggesting a possible common history of past geographic isolation in this region, which would have thus translated into a similarly high level of genetic differentiation between populations. The Coral Triangle is a well known area of major biogeographic breaks for marine fauna (Rocha et al., 2007; Carpenter et al., 2011). The phylogeographic patterns uncovered within the Coral Triangle for a proportion of marine animal species with wide Indo-West Pacific distribution point to PlioPleistocene vicariance (Barber et al., 2006; Carpenter et al., 2011). The vicariance hypothesis may be invoked to explain the high level of genetic differentiation among stingray populations in the Indo-Malay-Papua archipelago. However, a more exhaustive and finer-grained geographic sampling is required to test this hypothesis in the three stingray species investigated in the present paper.

Alternatively, the general pattern of increasing genetic differentiation with geographic distance in $N$. kublii may be caused, at least in part, by IBD, as a result of genetic drift at neutral loci locally balanced by low levels of gene flow. The estimates of genetic differentiation $\left(F_{s t}\right)$ in benthic teleosts for which IBD patterns were observed were $\sim 0.008$ (Hypoplectrus puella; Puebla et al., 2009), $\sim 0.020$ (Solea solea; Borsa et al., 1997b), 0.030 (Platichthys flesus; Borsa et al., 1997a), 0.034 (Psetta maxima; Blanquer et al., 1992), 0.091 (Myripristis berndti; Muths et al., 2011), $\sim 0.100$ (Acanthurus triostegus; Planes and Fauvelot, 2002), and $\sim 0.259$ (Eleutheronema tetradactylum; Horne et al., 2011), for a $3,000 \mathrm{~km}$ geographic distance, to be compared with $N$. kublii ( 0.375). Marine teleosts, including species that are sedentary as adults, are often broadcast spawners and have a pelagic larval stage, two traits which are assumed to enhance gene flow between local populations. Stingrays are viviparous (Hamlett and Hysell, 1998) and only the active movement of juveniles or adults potentially translates into gene flow, thus partly explaining a possible higher level of genetic differentiation in N. kublii than generally observed in coastal benthic teleosts where an IBD pattern has been observed. This is further supported by tagging experiments in N. kublii, which indicate this as a sedentary species (Pierce et al., 2011).

Also, deep oceanic waters likely constitute a barrier for the movements of stingray species from shallow benthic habitats, like D. brevicaudata (Le Port and Lavery, 2012) and possibly N. kublii and the two other stingray species surveyed. The sharp delineation of three N. kublii populations in the central part of the Indo-Malay-Papua archipelago, as apparent even from the limited sampling of the present study, may be partly explained by the effect of deep-sea barriers restricting the migration of individuals in some regions (e.g., between the Flores Sea and the Banda Sea). However, it is still possible that geographically tighter sampling would reveal smoother transitions between populations. Thus, the present phylogeographic 
structure of N. kublii in the Indo-Malay archipelago may be caused by the superimposition of genetic differences resulting from past geographic isolation, IBD, and possibly the present effect of deep-sea barriers. Strong population subdivision could also be enhanced by philopatry, as shown in other elasmobranchs (Keeney et al., 2003, 2005; Feldheim et al., 2004; Duncan et al., 2006) and, incidentally, as suspected in both the narrow-barred Spanish mackerel and the fourfinger threadfin (Fauvelot and Borsa, 2011; Horne et al., 2011).

\section{3. 'Cryptic species' hypothesis}

To be able to assess whether the genetic clusters obtained in this study for N. kublii represent distinct evolutionary significant units and therefore constitute incipient species or even, perhaps, cryptic species as envisaged by Ward et al. (2008), would require a geographically denser and broader analysis of population genetic structure, and an extension of the current mitochondrial dataset. There is no evidence, from the available data thus far, that reproductively isolated entities (in short, cryptic species) are present in the three regions sampled in the Indo-Malay archipelago, i.e., the Indian Ocean coast of Java; the Bali Strait / Flores Sea area, and the Banda Sea. Actually, from the present evidence, one cannot discard the hypothesis that $N$. kublii populations are strongly differentiated because of low but geographically continuous gene flow. Neither was there an indication from the limited sample set analysed in this study, that H. gerrardi harbours cryptic species.

\subsection{Implications for management}

Whatever the evolutionary processes that have led to the strong geographic structure observed in $N$. kublii and two other Dasyatidae surveyed from the Indo-Malay-Papua archipelago, our findings indicate that under local overfishing the global genetic diversity of the species is likely to erode, putative locally adapted genetic traits may be lost, and the replenishment of depleted populations is expected to be minimal at the ecological timescale. Consequently, if the absence of management persists, localized extinctions or nearextinctions are predicted to occur in stingray populations throughout the intensively-exploited Indo-MalayPapua archipelago. It is arguable that in highly mobile elasmobranch species such as pelagic sharks and mobulid rays, conservation efforts have to be conducted at the regional scale (e.g., Ovenden et al., 2009). Because of sharp geographic composition synonymous to limited genetic exchange between local populations, N. kublii and other stingray species from the central Indo-West Pacific also need to be managed locally.

\section{Acknowledgements}

We are grateful to five reviewers for their insightful comments on a former version of the manuscript. We thank M. Zaini and K. Jamil for participating in the collection of samples, and A. Kusler for copyediting a previous version of this manuscript. I.S.A. benefitted from a 6-months fellowship under the BEST program of Agence inter-organismes de recherche pour le développement (AIRD), France, for working with P. Borsa and P. Berrebi at ISE-M. Conceived and designed the experiments: P. Borsa, ML, P. Berrebi. Performed the experiments: P. Borsa, ISA, ML. Analyzed the data: P. Borsa, P. Berrebi. Contributed reagents/materials/analysis tools: P. Borsa, ISA, P. Berrebi. Wrote the paper: P. Borsa. Funded by AIRD, 
IRD, ISE-M and LIPI-P2O; the funders had no role in study design, data collection and analysis, decision to publish, or preparation of the manuscript.

\section{References}

Atarhouch, T., Rami, M., Cattaneo-Berrebi, G., Ibanez, C., Augros, S., Boissin, E., Dakkak, A., Berrebi, P., 2003. Primers for EPIC amplification of intron sequences for fish and other vertebrate population genetic studies. Biotechniques 35, 676-682.

Barber, P.H., Erdmann, M.V., Palumbi, S.R., 2006. Comparative phylogeography of three codistributed stomatopods: origins and timing of regional lineage diversification in the Coral Triangle. Evolution 60, 1825-1839.

Begg, G.A., Friedland, K.D., Pearce, J.B., 1999. Stock identification and its role in stock assessment and fisheries management: an overview. Fisheries Res. 43, 1-8.

Belkhir, K., Borsa, P., Chikhi, L., Raufaste, N., Bonhomme, F., 2000. GENETIX version 4.02, logiciel sous WindowsTM pour la génétique des populations. CNRS UMR 5000, Université Montpellier 2, Montpellier (http://www.genetix.univmontp2.fr/genetix/).

Bellwood, D.R., Meyer, C.P., 2009. Searching for heat in a marine biodiversity hotspot. J. Biogeogr. 36, 569-576.

Berrebi, P., Boissin, E., Fang, F., Cattaneo-Berrebi, G., 2005. Intron polymorphism (EPIC-PCR) reveals phylogeographic structure of Zacco platypus in China: a possible target for aquaculture development. Heredity 94, 589-598.

Blaber, S.J.M., Dichmont, C.M., White, W., Buckworth, R., Sadiyah, L., Iskandar, B., Nurhakim, S., Pillans, R., Andamari, R., Dharmadi, Fahmi, 2009. Elasmobranchs in southern Indonesian fisheries: the fisheries, the status of the stocks and management options. Rev. Fish Biol. Fisheries 19, 367-391.

Blanquer, A., Alayse, J.-P., Berrada-Rkhami, O., Berrebi, P., 1992. Allozyme variation in turbot (Psetta maxima) and brill (Scophthalmus rhombus) (Osteichthyes, Pleuronectoformes, Scophthalmidae) throughout their range in Europe. J. Fish Biol. 41, 725-736.

Borsa, P., 2003. Genetic structure of round scad mackerel Decapterus macrosoma (Carangidae) in the Indo-Malay archipelago. Mar. Biol. 142, 575-581.

Borsa, P., Blanquer, A., Berrebi, P., 1997a. Genetic structure of the flounders Platichthys flesus and P. stellatus at different geographic scales. Mar. Biol. 129, 233-246.

Borsa, P., Collet, A., Durand, J.-D., 2004. Nuclear-DNA markers confirm the presence of two anchovy species in the Mediterranean. C. R. Biol. 327, 1113-1123.

Borsa, P., Naciri, M., Bahri, L., Chikhi, L., García de León, F.J., Kotoulas, G., Bonhomme, F., 1997b. Zoogéographie infraspécifique de la mer Méditerranée. Analyse des données génétiques populationnelles sur seize espèces atlanto-méditerranéennes (poissons et invertébrés). Vie Milieu 47, 295-305.

Briggs, J.C., 2005. The marine East Indies: diversity and speciation. J. Biogeogr. 32, 1517-1522.

Carpenter, K.E., Barber, P.H., Crandall, E.D., Ablan-Lagman, M.C.A., Ambariyanto, Mahardika, G.N., Manjaji-Matsumoto, B.M., Juinio-Meñez, M.A., Santos, M.D., Starger, C.J., Toha, A.H.A., 2011. Comparative phylogeography of the Coral Triangle and implications for marine management. J. Mar. Biol. 2011, 396982, 14 p.

Chenuil, A., Hoareau, T.B., Egea, E., Penant, G., Rocher, C., Aurelle, D., Mokhtar-Jamai , K., Bishop, J.D.D., Boissin, E., Diaz, A., Krakau, M., Luttikhuizen, P.C., Patti, F.P., Blavet, N., Mousset, S., 2010. An efficient method to find potentially universal population genetic markers, applied to metazoans. BMC Evol. Biol. 10, 276.

Chevolot, M., Ellis, J.R., Rijnsdorp, A.D., Stam, W.T., Olsen, J.L., 2008. Temporal changes in allele frequencies but stable genetic diversity over the past 40 years in the Irish Sea population of thornback ray, Raja clavata. Heredity 101, 120-126.

Chevolot, M., Hoarau, G., Rijnsdorp, A.D., Stam, W.T., Olsen, J.L., 2006. Phylogeography and population structure of thornback rays (Raja clavata L., Rajidae). Mol. Ecol. 15, 3693-3705.

Chow, S., Hazama, K., 1998. Universal primers for S7 ribosomal protein gene introns in fish. Mol. Ecol. 7, 1255-1256. 
Chow, S., Takeyama, H., 1998. Intron length variation observed in the creatine kinase and ribosomal protein genes of the swordfish Xiphias gladius. Fisheries Sci. 64, 397-402.

Creer, S., 2007. Choosing and using introns in molecular phylogenetics. Evol. Bioinform. 3, 99-108.

Dudgeon, C.L., Broderick, D., Ovenden, J.R., 2009. IUCN classification zones concord with, but underestimate, the population genetic structure of the zebra shark Stegostoma fasciatum in the Indo-West Pacific. Mol. Ecol. 18, 248-261.

Duncan, K.M., Martin, A.P., Bowen, B.W., De Couet, H.G., 2006. Global phylogeography of the scalloped hammerhead shark (Sphyrna lewini). Mol. Ecol. 15, 2239-2251.

Ellegren, H., 2004. Microsatellites: simple sequences with complex evolution. Nature Rev. Genet. 5, 435-445.

Falush, D., Stephens, M., Pritchard, J., 2007. Inference of population structure using multilocus genotype data: dominant markers and null alleles. Mol. Ecol. Resour. 7, 574-578.

Fauvelot, C., Borsa, P., 2011. Patterns of genetic isolation in narrow-barred Spanish mackerel (Scomberomorus commerson) across the Indo-West Pacific. Biol. J. Linn. Soc. 104, 886-902.

Feldheim, K.A., Gruber, S.H., Ashley, M.V., 2004. Reconstruction of parental microsatellite genotypes reveals female polyandry and philopatry in the lemon shark, Negaprion brevirostris. Evolution 58, 2332-2342.

Forsskål, P., 1775. Descriptiones animalium, avium, amphibiorum, piscium, insectorum, vermium; quae in itinere orientali observavit Petrus Forskål (post mortem auctoris edidit Carsten Niebuhr). Adjuncta est materia medica kahirina atque tabula maris Rubri geographica. Mölleri, Hauniae, xxxiv+164 pp.

Francisco, S.M., Faria, C., Lengkeek, W., Vieira, M.N., Velasco, E.M., Almada, V.C., 2011. Phylogeography of the shanny Lipophrys pholis (Pisces: Blenniidae) in the NE Atlantic records signs of major expansion event older than the last glaciations. J. Exp. Mar. Biol. Ecol. 403, 14-20.

Friedberg, F., Rhoads, A.R., 2002. Multiple calmodulin genes in fish. Mol. Biol. Rep. 29, 377-382.

Gaither, M.R., Bowen, B.W., Bordenave, T.-R., Rocha, L.A., Newman, S.J., Gomez J.A., van Herwerden L., Craig, M.T., 2011. Phylogeography of the reef fish Cephalopholis argus (Epinephelidae) indicates Pleistocene isolation across the indo-pacific barrier with contemporary overlap in the coral triangle. BMC Evol. Biol. 11, 189.

Garnier-Géré, P., Dillmann, C., 1992. A computer program for testing pairwise linkage disequilibria in subdivided populaChowtions. J. Hered. 83, 239.

Garza, J.C., Freimer, N.B., 1996. Homoplasy for size at microsatellite loci in humans and chimpanzees. Genome Res. 6, 211 -217.

González-Wangüemert, M., Cánovas, F., Pérez-Ruzafa, A., Marcos, C., Alexandrino, P., 2010. Connectivity patterns inferred from the genetic structure of white seabream (Diplodus sargus L.). J. Exp. Mar. Biol. Ecol. 383, 23-31.

Gray, J.E., 1851. List of the specimens of fish in the collection of the British Museum. Part I. -Chondropterygii. E. Newman, London, $\mathrm{x}+160$ pp., 2 pls.

Hamlett, W.C., Hysell, M.K., 1998. Uterine specializations in elasmobranchs. J. Exp. Zool. 282, 438-459.

Hassan, M., Lemaire, C., Fauvelot, C., Bonhomme, F., 2002. Seventeen new exon-primed intron-crossing polymerase chain reaction amplifiable introns in fish. Mol. Ecol. Notes 2, 334-340.

Haustein, S., Tunger, D., Heinrichs G., Baelz, G., 2011. Reasons for and developments in international scientific collaboration: does an Asia-Pacific research area exist from a bibliometric point of view? Scientometrics 86, 727-746.

Heist, E.J., Jenkot, J.L., Keeney, D.B., Lane, R.L., Moyer, G.R., Reading, B.J., Smith, N.L., 2003. Isolation and characterization of polymorphic microsatellite loci in nurse shark (Ginglymostoma cirratum). Mol. Ecol. Notes 3, 59-61.

Hemmer-Hansen, J., Nielsen, E.E.G., Grønkjær, P., Loeschcke, V., 2007. Evolutionary mechanisms shaping the genetic population structure of marine fishes; lessons from the European flounder (Platichthys flesus L.). Mol. Ecol. 16, 3104-3118

Hoarau, G., Rijnsdorp, A.D., van der Veer, H.W., Stam, W.T., Olsen, J.L., 2002. Population structure of plaice (Pleuronectes platessa L.) in northern Europe: microsatellites revealed large-scale spatial and temporal homogeneity. Mol. Ecol. 11, 1165-1176.

Hoareau, T.B., Bosc, P., Valade P., Berrebi, P., 2007. Gene flow and genetic structure of Sicyopterus lagocephalus in the south-western Indian Ocean, assessed by intron-length polymorphism. J. Exp. Mar. Biol. Ecol. 349, 223-234. 
Horne, J.B., Momigliano, P., Welch, D.J., Newman, S.J., van Herwerden, L. 2011. Limited ecological population connectivity suggests low demands on self-recruitment in a tropical inshore marine fish (Eleutheronema tetradactylum: Polynemidae). Mol. Ecol. 20, 2291-2306.

Jones D.B., Jerry D.R., McCormick, M.I., Bay, L.K., 2010. The population genetic structure of a common tropical damselfish on the Great Barrier Reef and eastern Papua New Guinea. Coral Reefs 29:455-467.

Keeney, D.B., Heupel, M., Hueter ,R.E., Heist, E.J., 2003. Genetic heterogeneity among blacktip shark, Carcharbinus limbatus, continental nurseries along the US Atlantic and Gulf of Mexico. Mar. Biol. 143, 1039-1046.

Keeney, D.B., Heupel, M.R., Hueter, R.E., Heist, E.J. 2005. Microsatellite and mitochondrial DNA analyses of the genetic structure of blacktip shark (Carcharbinus limbatus) nurseries in the northwestern Atlantic, Gulf of Mexico, and Caribbean Sea. Mol. Ecol. 14, 1911-1923.

Kotoulas, G., Bonhomme, F., Borsa, P., 1995. Genetic structure of the common sole, Solea vulgaris, at different geographic scales. Mar. Biol. 122, 361-375.

Le Port, A., Lavery, S., 2012. Population structure and phylogeography of the short-tailed stingray, Dasyatis brevicaudata (Hutton 1875), in the Southern Hemisphere. J. Hered. 103, 174-185.

Magsino, R.M., Juinio-Meñez, M.A., 2008. The influence of contrasting life history traits and oceanic processes on genetic structuring of rabbitfish populations Siganus argenteus and Siganus fuscescens along the eastern Philippine coasts. Mar. Biol. 154, 519-532.

Matschiner, M., Hanel, R., Salzburger, W., 2009. Gene flow by larval dispersal in the Antarctic notothenioid fish Gobionotothen gibberifrons. Mol. Ecol. 18, 2574-2587.

Meijaard, E., 2011. Indonesia has its share of scientists, so where's the science? Jakarta Globe, Jakarta (http://www.thejakartaglobe.com/opinion/indonesia-has-its-share-of-scientists-so-wheres-the-science/430931; 23 March 2011).

McCusker, M., Bentzen, P., 2010. Historical influences dominate the population genetic structure of a sedentary marine fish, Atlantic wolfish (Anarbichas lupus), across the North Atlantic Ocean. Mol. Ecol. 19, 4228-4241.

Mobley, K.B., Small, C.M., Jue, N.K., Jones, A.G., 2010. Population structure of the dusky pipefish (Syngnathus floridae) from the Atlantic and Gulf of Mexico, as revealed by mitochondrial DNA and microsatellite analyses. J. Biogeogr. 37, 1363-1377.

Müller, J., Henle, J., 1841. Systematische Beschreibung der Plagiostomen. Veit und Comp., Berlin, xxii+200 pp., 60 pls.

Muths, D., Tessier, E., Gouws, G., Craig, M., Mwale, M., Mwaluma, J., Mwandya, A., Bourjea, J., 2011. Restricted dispersal of the reef fish Myripristis berndti at the scale of the SW Indian Ocean. Mar. Ecol. Prog. Ser. 443, 167-180.

Nei, M., Chesser, R.K., 1983. Estimation of fixation indices and gene diversities. Ann. Hum. Genet. 47, 253-259.

Ovenden, J.R., Kashiwagi, T., Broderick, D., Giles, J., Salini, J., 2009. The extent of population genetic subdivision differs among four co-distributed shark species in the Indo-Australian archipelago. BMC Evol. Biol. 9, 40.

Ovenden, J.R., Morgan, J.A.T., Street, R., Tobin, A., Simpfendorfer, C., Macbeth, W., Welch, D., 2011. Negligible evidence for regional genetic population structure for two shark species Rhizoprionodon acutus (Rüppell, 1837) and Sphyrna lewini (Griffith \& Smith, 1834) with contrasting biology. Mar. Biol. 158, 1497-1509.

Palumbi, S., Martin, A., Romano, S., McMillan, W.O., Stice, L., Grabowski, G., 1991. The simple fool's guide to PCR, v. 2.0. University of Hawai'i, Honolulu, 47 pp.

Pauly, D., 1994. On the sex of fish and the gender of scientists: a collection of essays in fisheries science. Chapman and Hall, London, $250 \mathrm{pp}$.

Pierce, S.J., Scott-Holland, T.B., Bennett, M.B., 2011. Community composition of elasmobranch fishes utilizing intertidal sand flats in Moreton Bay, Queensland, Australia. Pac. Sci. 65, 235-247.

Planes, S., Fauvelot, C., 2002. Isolation by distance and vicariance drive genetic structure of a coral reef fish in the Pacific Ocean. Evolution 56, 378-399.

Plank, S.M., Lowe, C.G., Feldheim, K.A., Wilson, R.R., Brusslan, J.A., 2010. Population genetic structure of the round stingray Urobatis halleri (Elasmobranchii: Rajiformes) in southern California and the Gulf of California. J. Fish Biol. 77, 329-340. 
Portnoy, D.S., Heist, E.J., 2012. Molecular markers: progress and prospects for understanding reproductive ecology in elasmobranchs. J. Fish Biol. (doi:10.1111/j.1095-8649.2011.03206.x)

Puebla, O., Bermingham, E., Guichard, F., 2009. Estimating dispersal from genetic isolation by distance in a coral reef fish (Hypoplectrus puella). Ecology 90, 3087-3098.

Purcell, J.F.H., Cowen, R.K., Hughes, C.R., Williams, D.A., 2009. Population structure in a common Caribbean coral-reef fish: implications for larval dispersal and early life-history traits. J. Fish Biol. 74, 403-417.

Rice, W.R., 1989. Analyzing tables of statistical tests. Evolution 43, 223-225.

Rocha, L.A., Craig, M.T., Bowen, B.W., 2007. Phylogeography and the conservation of coral reef fishes. Coral Reefs 26, 501-512.

Rohfritsch, A., Borsa, P., 2005. Genetic structure of Indian scad mackerel Decapterus russelli: Pleistocene vicariance and secondary contact in the central Indo-West Pacific seas. Heredity 95, 315-322.

Roldán, M.I., García-Marín, J.L., Utter, F.M., Pla, C., 1998. Population genetic structure of European hake, Merluccius merluccius. Heredity 81, 327-334.

Rolland, J.L., Bonhomme, F., Lagardère, F., Hassan, M., Guinand, B., 2007. Population structure of the common sole (Solea solea) in the Northeastern Atlantic and the Mediterranean Sea: revisiting the divide with EPIC markers. Mar. Biol. 151, 327-341.

Rousset, F., 1997. Genetic differentiation and estimation of gene flow from F-statistics under isolation by distance. Genetics 145 , 1219-1228.

Ryan, W.B.F., Carbotte, S.M., Coplan, J.O., O’Hara, S., Melkonian, A., Arko, R., Weissel, R.A., Ferrini, V., Goodwillie, A., Nitsche, F., Bonczkowski, J., Zemsky, R., 2009. Global multi-resolution topography synthesis. Geochem. Geophys. Geosyst. 10, Q03014.

Sadovy, Y., 2005. Trouble on the reef: the imperative for managing vulnerable and valuable fisheries. Fish Fisheries 6, 167-185.

Schluessel, V., Broderick, D., Collin, S.P., Ovenden, J.R., 2010. Evidence for extensive population structure in the white-spotted eagle ray within the Indo-Pacific inferred from mitochondrial gene sequences. J. Zool. 281, 46-55.

Shaklee, J., Bentzen, P., 1998. Genetic identification of stocks of marine fish and shellfish. Bull. Mar. Sci. 62, 589-621.

Sokal, R.R., Rohlf, F.J., 1995. Biometry. The principles and practice of statistics in biological research, $3^{\text {rd }}$ edn. Freeman and Co, New York, 776 p.

Timm, J., Planes, S., Kochzius, M., 2012. High similarity of genetic population structure in the false clown anemonefish (Amphiprion ocellaris) found in microsatellite and mitochondrial control region analysis. Conserv. Genet. 13, 693-706.

Walsh, P.S., Metzger, D.A., Higuchi, R., 1991. Chelex 100 as a medium for simple extraction of DNA for PCR-based typing from forensic material. Biotechniques 10, 506-513.

Ward, R.D., 2000. Genetics in fisheries management. Hydrobiologia 420, 191-201.

Ward, R.D., Holmes, B.H., White, W.T., Last, P.R., 2008. DNA barcoding Australian chondrichthyans: results and potential uses in conservation. Mar. Freshw. Res. 59, 57-71.

Weir, B.S., Cockerham, C.C., 1984. Estimating F-statistics for the analysis of population structure. Evolution 38, 822-831.

White, W.T., Dharmadi, 2007. Species and size compositions and reproductive biology of rays (Chondrichthyes, Batoidea) caught in target and non-target fisheries in eastern Indonesia. J. Fish Biol. 70, 1809-1837.

White, W.T., Kyne, P.M. 2010. The status of chondrichthyan conservation in the Indo-Australasian region. J. Fish Biol. 76, 20902117. 
Table 1

PCR primers used to amplify size-polymorphic introns in three Indo-West Pacific stingray species. Intron no.: assumed intron number in teleost fishes.

\begin{tabular}{|c|c|c|c|c|}
\hline $\begin{array}{l}\text { Gene or gene } \\
\text { family }\end{array}$ & $\begin{array}{l}\text { Intron } \\
\text { no. }\end{array}$ & $\begin{array}{l}\text { Locus (loci), } \\
\text { primer name }\end{array}$ & Primer sequence & Reference \\
\hline Actin & 2 & $\begin{array}{l}\text { Act-2 } \\
\text { Act-2-F } \\
\text { Act-2-R }\end{array}$ & $\begin{array}{l}\text { 5'-GCTATAACCCTCGTAGATGGGCAC-3' } \\
\text { 5'-ATCTGGCACCACACCTTCTACAA-3' }\end{array}$ & Atarhouch et al. (2003) \\
\hline Aldolase B & 5 & $\begin{array}{l}\text { AldoB5 } \\
\text { Aldo3F } \\
\text { Aldo2R }\end{array}$ & $\begin{array}{l}\text { 5'- TCCTGCCTGATGGAACCC-3' } \\
\text { 5'- CAGGTACACATGGTGGTC-3' }\end{array}$ & Hassan et al. (2002) \\
\hline Calmodulin & 3 & $\begin{array}{l}\text { Cam-3 } \\
\text { Cam-3-F } \\
\text { Cam-3-R }\end{array}$ & $\begin{array}{l}\text { 5'-TGACGGAGCTCTGCAGCACTGAC-3' } \\
\text { 5'-GTGAGGAGGAGCTCCGTGAGGC-3' }\end{array}$ & Atarhouch et al. (2003) \\
\hline Creatine kinase & 6 & $\begin{array}{l}C K \\
C K 6-5 \\
C K 7-3\end{array}$ & $\begin{array}{l}\text { 5'-GACCACCTCCGAGTCATCTCSATG-3' a } \\
\text { 5'- CAGGTGCTCGTTCCACATGAA-3' }\end{array}$ & Palumbi et al. (1991) \\
\hline $\begin{array}{l}\text { Glyceraldehyde-3-phosphate } \\
\text { dehydrogenase }\end{array}$ & 2 & $\begin{array}{l}G p d 2 \\
G p d 2 F \\
G p d 3 R\end{array}$ & $\begin{array}{l}\text { 5'-GCCATCAATGACCCCTTCATCG-3' } \\
\text { 5'-TTGACCTCACCCTTGAAGCGGCCG-3' }\end{array}$ & Hassan et al. (2002) \\
\hline Ribosomal protein & 1 & $\begin{array}{l}\text { RP } \\
\text { RPEX1F } \\
\text { RPEX2R }\end{array}$ & $\begin{array}{l}\text { 5'-TGGCCTCTTCCTTGGCCGTC-3' } \\
\text { 5'-AACTCGTCTGGCTTT'TCGCC-3' }\end{array}$ & Chow and Takeyama (1998) \\
\hline
\end{tabular}

a $\mathrm{S}=\mathrm{C}$ or $\mathrm{G}$, with approximately equal probabilities 
Table 2

Himantura gerrardi. Allelic frequencies at 7 presumptive intron loci sampled from the Indo-Malay-Papua archipelago. Alleles were designated from the approximate size of the PCR-amplified fragment (in base pairs). Five different, presumptive intron loci, here designed as Cam-3 a-e, were scored using the Cam-3 primer pair (Table 1). Estimates of genetic differentiation over all samples and loci: ${ }^{\wedge} \theta=0.123$ (permutation test, 1000 random permutations: $P<0.01$ ) and ${ }^{\wedge} G s t=0.159$. Hyphen: no data.

\begin{tabular}{|c|c|c|c|c|c|}
\hline \multirow{2}{*}{$\begin{array}{l}\text { Locus, } \\
\text { allele }\end{array}$} & \multicolumn{5}{|l|}{ Sample } \\
\hline & Sunda Strait & Java Sea & Indian Ocean & West Papua & Unknown \\
\hline \multicolumn{6}{|l|}{ Act-2 } \\
\hline 238 & 0.57 & 0.58 & 0.70 & - & 0.56 \\
\hline 225 & 0.43 & 0.43 & 0.20 & - & 0.44 \\
\hline 210 & 0 & 0 & 0.10 & - & 0 \\
\hline$(N)$ & (7) & (21) & (5) & - & (8) \\
\hline${ }^{\prime} f$ & -0.091 & -0.063 & 0.238 & - & -0.750 \\
\hline \multicolumn{6}{|l|}{ Cam-3 a } \\
\hline 206 & 0 & 0 & 0.17 & - & 0.39 \\
\hline 203 & 0.07 & 0.37 & 0 & - & 0 \\
\hline 200 & 0.93 & 0.63 & 0.83 & - & 0.61 \\
\hline$(N)$ & (7) & (19) & (3) & - & (9) \\
\hline$\wedge_{f}$ & 0 & -0.333 & 0 & - & -0.600 \\
\hline \multicolumn{6}{|l|}{ Cam-3 b } \\
\hline 178 & 0 & 0 & 0 & 0 & 0.17 \\
\hline 175 & 0.71 & 0.58 & 0.90 & 0 & 0.61 \\
\hline 173 & 0.29 & 0.39 & 0.10 & 0 & 0.06 \\
\hline 171 & 0 & 0.03 & 0 & 1 & 0.17 \\
\hline$(N)$ & (7) & $(18)$ & (5) & (1) & (9) \\
\hline$\wedge^{\prime}$ & -0.333 & $-0.624 *$ & 0 & - & -0.116 \\
\hline \multicolumn{6}{|l|}{ Cam-3c } \\
\hline 161 & 0 & 0.13 & 0 & 0 & 0.06 \\
\hline 158 & 0.43 & 0.32 & 0 & 0 & 0.44 \\
\hline 155 & 0.57 & 0.55 & 0.90 & 1 & 0.44 \\
\hline 152 & 0 & 0 & 0.10 & 0 & 0.06 \\
\hline$(N)$ & (7) & (19) & (5) & (2) & (8) \\
\hline if & -0.714 & -0.251 & 0 & - & -0.380 \\
\hline \multicolumn{6}{|l|}{ Cam-3d } \\
\hline 140 & 0.71 & 0.80 & 0.17 & - & 0.17 \\
\hline 138 & 0.29 & 0.20 & 0.83 & - & 0.67 \\
\hline 136 & 0 & 0 & 0 & - & 0.17 \\
\hline$(N)$ & $(7)$ & (10) & (3) & - & $(9)$ \\
\hline$\wedge^{\prime}$ & 0.368 & -0.200 & 0 & - & -0.053 \\
\hline \multicolumn{6}{|l|}{ Cam-3e } \\
\hline 127 & 0 & 0 & 0 & 0 & 0.17 \\
\hline 126 & 0 & 0.03 & 0 & 0 & 0 \\
\hline 125 & 1 & 0.97 & 1 & 1 & 0.83 \\
\hline$(N)$ & $(7)$ & (19) & (5) & (2) & (7) \\
\hline$\wedge f$ & - & 0 & - & - & 0.636 \\
\hline \multicolumn{6}{|l|}{ CK } \\
\hline 175 & 0.64 & 0.63 & 0.67 & 1 & 0.56 \\
\hline 173 & 0.36 & 0.37 & 0.33 & 0 & 0.44 \\
\hline$(N)$ & (7) & (19) & (3) & (2) & (9) \\
\hline${ }^{\prime} f$ & -0.500 & $0.565^{*}$ & 1 & - & -0.297 \\
\hline
\end{tabular}

${ }^{*} P<0.05$ 


\section{Table 3}

Neotrygon kublii. Allelic frequencies at 4 presumptive intron loci in 6 samples from the Indo-Malay-Papua archipelago. Alleles were designated from the approximate size of the PCR amplified fragment (in base pairs). Two different, presumptive intron loci, here designed as Cam-3 slow and fast according to the motility of the expressed DNA bands, were scored using the Cam-3 primer pair (Table 1). Estimates of genetic differentiation over all samples and loci: ${ }^{\wedge} \theta=$ 0.336 (permutation test, 1000 random permutations: $P<0.001$ ) and ${ }^{\wedge} G s t=0.316$.

\begin{tabular}{|c|c|c|c|c|c|c|}
\hline \multirow{2}{*}{$\begin{array}{l}\text { Locus, } \\
\text { allele }\end{array}$} & \multicolumn{6}{|l|}{ Sample } \\
\hline & Indian Ocean $^{\mathrm{a}}$ & Indian Ocean ${ }^{\mathrm{b}}$ & Bali Strait & Flores Sea & Tomini Bay & Banda Sea \\
\hline \multicolumn{7}{|c|}{ Cam-3 slow } \\
\hline 430 & 0 & 0 & 0 & 0 & 0 & 0.05 \\
\hline 400 & 0.96 & 0.94 & 0.93 & 0.82 & 1 & 0.91 \\
\hline 385 & 0 & 0 & 0 & 0.11 & 0 & 0 \\
\hline 370 & 0.04 & 0.06 & 0.08 & 0.08 & 0 & 0.04 \\
\hline$(N)$ & (38) & (9) & (20) & (19) & (3) & (38) \\
\hline$\hat{A}^{\prime}$ & -0.028 & 0 & -0.056 & -0.135 & - & 0.245 \\
\hline \multicolumn{7}{|c|}{ Cam-3 fast } \\
\hline 300 & 0.18 & 0.33 & 0.68 & 0.94 & 0 & 0.88 \\
\hline 282 & 0.74 & 0.39 & 0.33 & 0.06 & 1 & 0.12 \\
\hline 264 & 0.08 & 0.28 & 0 & 0 & 0 & 0 \\
\hline$(N)$ & (38) & (9) & (20) & (18) & (3) & (39) \\
\hline$\wedge_{f}^{\prime}$ & $-0.240^{*}$ & 0.297 & 0 & -0.030 & - & -0.118 \\
\hline \multicolumn{7}{|l|}{$C K$} \\
\hline 368 & 0.46 & 0 & 0 & 0.03 & 0 & 0 \\
\hline 366 & 0.01 & 0 & 0.43 & 0 & 0 & 0.04 \\
\hline 363 & 0.28 & 0.67 & 0.25 & 0.22 & 0 & 0.16 \\
\hline 361 & 0.24 & 0.33 & 0.33 & 0.72 & 1 & 0.74 \\
\hline 359 & 0 & 0 & 0 & 0.03 & 0 & 0.06 \\
\hline$(N)$ & (37) & (9) & (20) & (16) & (4) & (34) \\
\hline$\wedge f$ & 0.144 & 0.543 & -0.126 & -0.268 & - & 0.121 \\
\hline \multicolumn{7}{|l|}{$G p d 2$} \\
\hline 173 & 0 & 0 & 0 & 0.15 & 0 & 0 \\
\hline 169 & 0 & 0 & 0 & 0.03 & 0 & 0 \\
\hline 167 & 0.82 & 0.83 & 0.89 & 0.82 & 1 & 0.23 \\
\hline 164 & 0.18 & 0.17 & 0.11 & 0 & 0 & 0.77 \\
\hline$(N)$ & (38) & (9) & (19) & (17) & (4) & (33) \\
\hline$\wedge_{f}^{\prime}$ & -0.037 & -0.143 & -0.091 & -0.150 & - & -0.106 \\
\hline
\end{tabular}

a Binuangen sample (Fig. 1A); b Malang sample (Fig. 1A)

${ }^{*} P<0.05$ 


\section{Table 4}

Taeniura lymna. Allelic frequencies at 5 presumptive intron loci in 3 samples from the Indo-Malay archipelago. Alleles were designated from the approximate size of the PCR amplified fragment (in base pairs). Three different, presumptive intron loci differing by the mobility of the expressed DNA bands, were scored using the AldoB-5 primer pair (Table 1). Estimates of genetic differentiation over all samples and loci: ${ }^{\wedge} \theta=0.095$ (permutation test, 1000 random permutations: $P<0.01$ ) and ${ }^{\wedge}$ Gst $=0.074$.

\begin{tabular}{|c|c|c|c|}
\hline \multirow{2}{*}{$\begin{array}{c}\text { Locus, } \\
\text { allele }\end{array}$} & \multicolumn{3}{|l|}{ Sample } \\
\hline & Java Sea & Flores Sea & Molucca Sea \\
\hline \multicolumn{4}{|c|}{ AldoB5 slow } \\
\hline 284 & 0.21 & 0.46 & 0.39 \\
\hline 280 & 0.79 & 0.54 & 0.61 \\
\hline$(N)$ & $(7)$ & (12) & (14) \\
\hline$\wedge^{\prime}$ & 0.625 & 0.203 & 0.285 \\
\hline \multicolumn{4}{|c|}{ AldoB5 fast } \\
\hline 123 & 0.57 & 0.08 & 0.17 \\
\hline 119 & 0.43 & 0.92 & 0.83 \\
\hline$(N)$ & $(7)$ & $(12)$ & (12) \\
\hline$\wedge^{\prime}$ & -0.091 & -0.048 & -0.158 \\
\hline \multicolumn{4}{|c|}{ AldoB5 faster } \\
\hline 087 & 0.29 & 0.13 & 0.14 \\
\hline 085 & 0.71 & 0.88 & 0.86 \\
\hline$(N)$ & (7) & (12) & (14) \\
\hline$\wedge^{\prime}$ & -0.333 & 0.645 & -0.130 \\
\hline \multicolumn{4}{|l|}{ CK } \\
\hline 138 & 0.29 & 0 & 0 \\
\hline 133 & 0.71 & 1 & 1 \\
\hline$(N)$ & (7) & (12) & (12) \\
\hline$\hat{f}^{\prime}$ & 0.368 & - & - \\
\hline \multicolumn{4}{|l|}{$R P$} \\
\hline 313 & 0 & 0.08 & 0 \\
\hline 296 & 0.21 & 0.17 & 0 \\
\hline 290 & 0.79 & 0.75 & 1 \\
\hline$(N)$ & (7) & $(12)$ & (12) \\
\hline$\wedge_{f}$ & 0.625 & 0.214 & - \\
\hline
\end{tabular}




\section{Table 5}

Population-pairwise multilocus ${ }^{\wedge} \theta$ (Weir and Cockerham, 1984) (above diagonal) in three stingray species from the IndoMalay-Papua archipelago, and ship distance between locations (in km, below diagonal, italics). ${ }^{*}, P<0.05$; **, $P<0.01$; ***, $P<0.001$ (permutation test; GENETIX 4.02; 1000 permutations); na, not applicable. A. Neotygon kublii. B. Himantura gerrardi and Taeniura lymna.

\begin{tabular}{|c|c|c|c|c|c|c|c|c|c|c|}
\hline \multirow{2}{*}{$\begin{array}{l}\text { Species, } \\
\text { Sample } \\
\end{array}$} & \multicolumn{10}{|l|}{ Sample } \\
\hline & Indian Ocean $^{\mathrm{a}}$ & \multicolumn{2}{|c|}{ Indian Ocean ${ }^{\mathrm{b}}$} & \multicolumn{2}{|c|}{ Bali Strait } & \multicolumn{2}{|c|}{ Flores Sea } & \multicolumn{2}{|c|}{ Tomini Bay } & Banda Sea \\
\hline \multicolumn{11}{|l|}{ Neotrygon kublii } \\
\hline Indian Ocean ${ }^{a}$ & 0 & $0.105^{* *}$ & & $0.210^{\text {****}}$ & & \multicolumn{2}{|c|}{$0.360^{* * *}$} & \multicolumn{2}{|c|}{$0.249^{* *}$} & $0.440^{* * *}$ \\
\hline Indian Ocean ${ }^{\mathrm{b}}$ & 823 & 0 & & $0.176^{* * *}$ & & \multicolumn{2}{|c|}{$0.326^{* * *}$} & \multicolumn{2}{|c|}{0.296} & $0.430^{* * *}$ \\
\hline Bali Strait & 1094 & 254 & & 0 & & \multicolumn{2}{|c|}{$0.153^{* * *}$} & \multicolumn{2}{|c|}{$0.366^{*}$} & $0.332^{* * *}$ \\
\hline Flores Sea & 1604 & 789 & & 638 & & \multicolumn{2}{|l|}{0} & \multicolumn{2}{|c|}{$0.486^{*}$} & \multirow{2}{*}{$0.290^{* * *}$} \\
\hline Tomini Bay & 3019 & 2101 & & 1920 & & \multicolumn{2}{|c|}{1375} & \multicolumn{2}{|l|}{0} & \\
\hline Banda Sea & 2330 & 1433 & & 1224 & & \multicolumn{2}{|c|}{695} & \multicolumn{2}{|c|}{729} & 0 \\
\hline \multicolumn{11}{|c|}{ a Binuangen, Apr. 2010; ' Malang, Oct. 2010} \\
\hline \multicolumn{11}{|l|}{ B } \\
\hline \multirow{2}{*}{$\begin{array}{l}\text { Species, } \\
\text { Sample }\end{array}$} & \multicolumn{10}{|l|}{ Sample } \\
\hline & Sunda Strait & Java Sea & Ind & $\operatorname{ian} O .^{a}$ & & es Sea & Molucca & Sea & West Papua & Unknown \\
\hline \multicolumn{11}{|l|}{ Himantura gerrardi } \\
\hline Sunda Strait & 0 & 0.009 & 0.1 & & - & & - & & 0.455 & $0.095 *$ \\
\hline Java Sea & 520 & 0 & $0.1^{\top}$ & $76^{* *}$ & - & & - & & $0.365^{*}$ & $0.136^{* * *}$ \\
\hline Indian Ocean a & 595 & 1075 & 0 & & - & & - & & 0.493 & 0.057 \\
\hline West Papua & 4126 & 3592 & 37 & & - & & - & & 0 & 0.286 \\
\hline Unknown & $n a$ & $n a$ & na & & - & & - & & na & 0 \\
\hline \multicolumn{11}{|l|}{ Taeniura lymna } \\
\hline Java Sea & 0 & - & - & & & & $0.148^{*}$ & & - & - \\
\hline Flores Sea & 1507 & - & - & & 0 & & 0.003 & & - & - \\
\hline Molucca Sea & 2405 & - & - & & & & 0 & & - & - \\
\hline
\end{tabular}

a two samples were pooled (Fig. 1) 


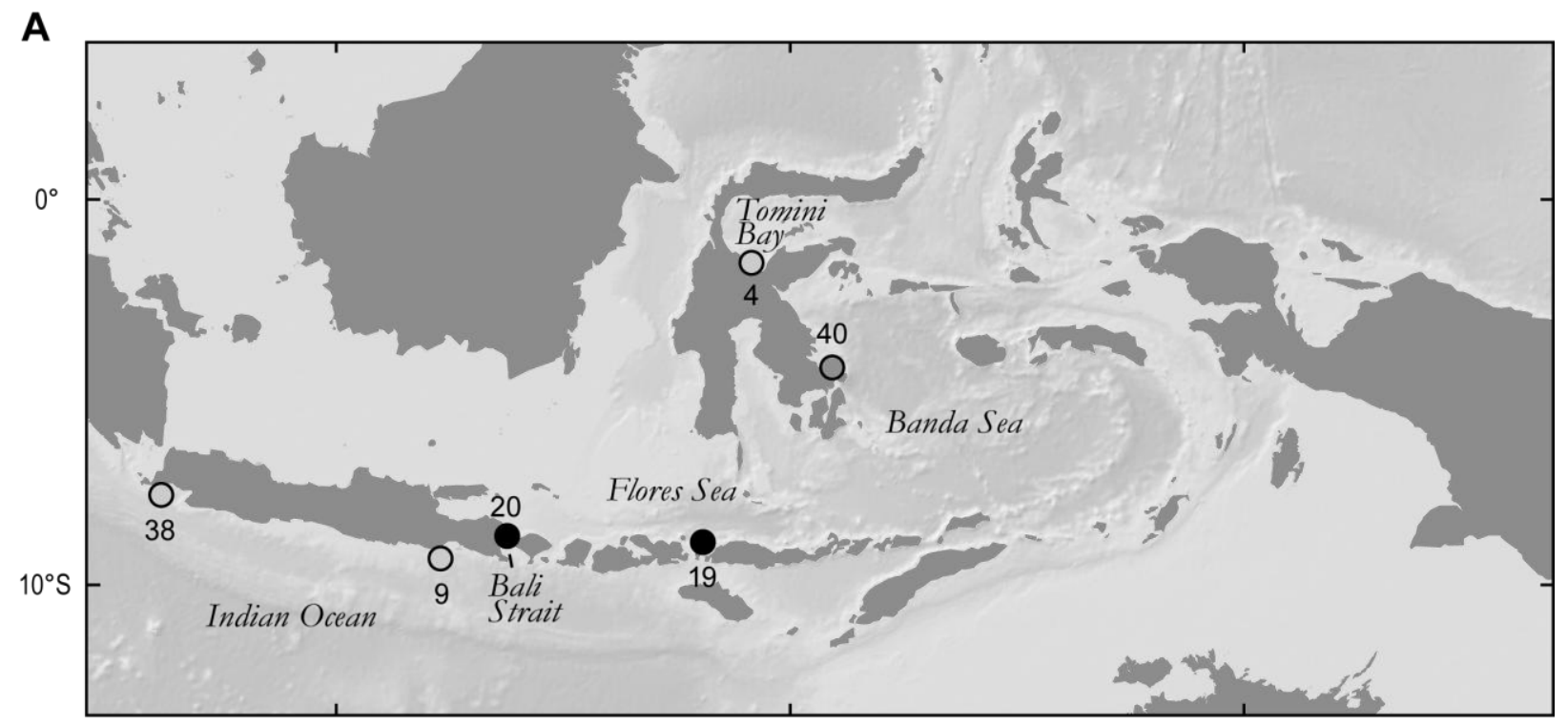

B

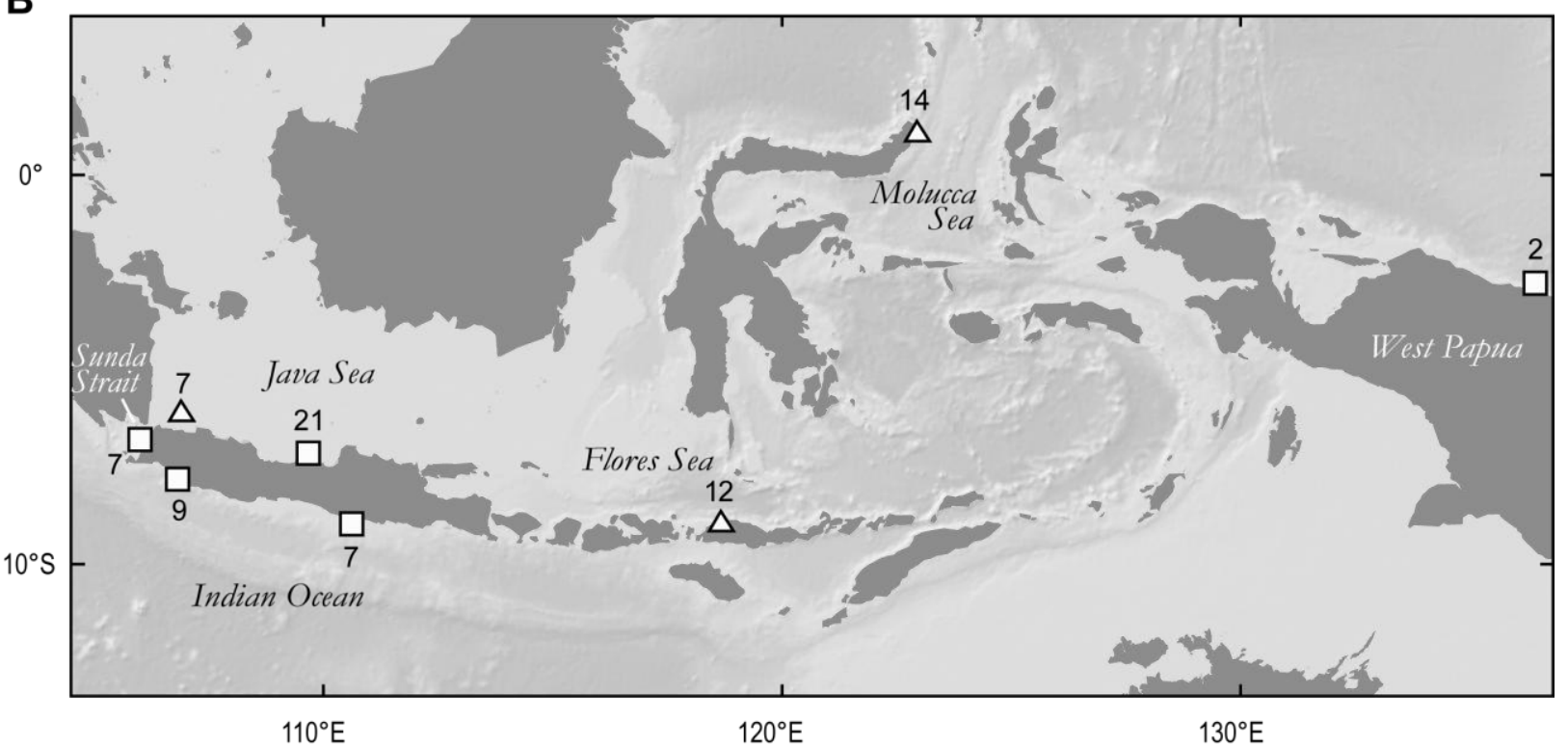

Fig. 1. Map of the Indo-Malay-Papua archipelago with sampling sites for three stingray species. Sample sizes indicated near symbols. Background topographic map from GeoMapApp (Ryan et al., 2009) (http://www.geomapapp.org). A. Neotrygon kublii (circles): grey tones (light grey, dark grey, black) illustrate the populations to which individuals were predominantly assigned according to Bayesian structure analysis (STRUCTURE: Falush et al., 2007; K=3). Indian Ocean, from West to East: Binuangen (Apr. 2010), Malang (Oct. 2010); Bali Strait: Banyuwangi (Oct. 2010); Flores Sea: Labuan Bajo (Oct. 2010); Tomini Bay: Poso (Jan. 2011); Banda Sea: Kendari (Oct. 2010). B. Himantura gerrardi (squares) and Taeniura lymna (triangles). Sunda Strait: Labuan (Oct. 2010); Indian Ocean, from West to East: Pelabuhan Ratu (Apr. 2010), Sadeng (Oct. 2010); Java Sea, from West to East: Pulau Pari (Nov. 2008) and Batang (Nov. 2007-Jan. 2008); Flores Sea: Labuan Bajo (Oct. 2010); Molucca Sea: Lembeh Strait (Nov. 2010); West Papua: Port Numbay (Nov. 2010). Not represented: an H. gerrardi sample of unknown origin landed in Batang (Jan. 2008). 


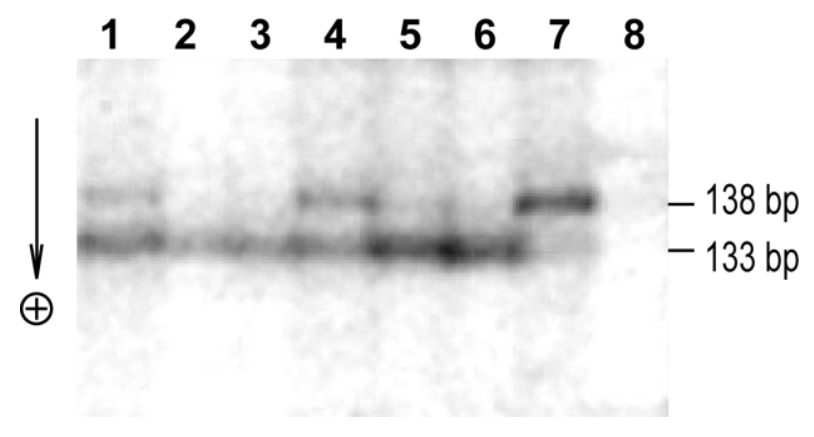

Fig. 2. Mendelian-like allele-size polymorphism detected from an electrophoresis gel of CY5-labelled, PCR-amplified introns at the $C K$ locus in ribbontail stingray

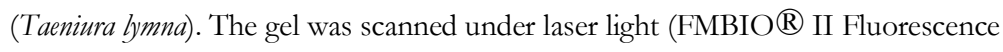
Imaging System, Hitachi Instruments, San José CA, U.S.A.) to detect fluorescent DNA bands. Two size-alleles were scored, with size indicated on the left margin of the image. Lanes 1, 4: heterozygotes 138/133; lanes 2, 3, 5, 6: homozygotes 133; lane 7: homozygote 138; lane 8: PCR control with no DNA template. 


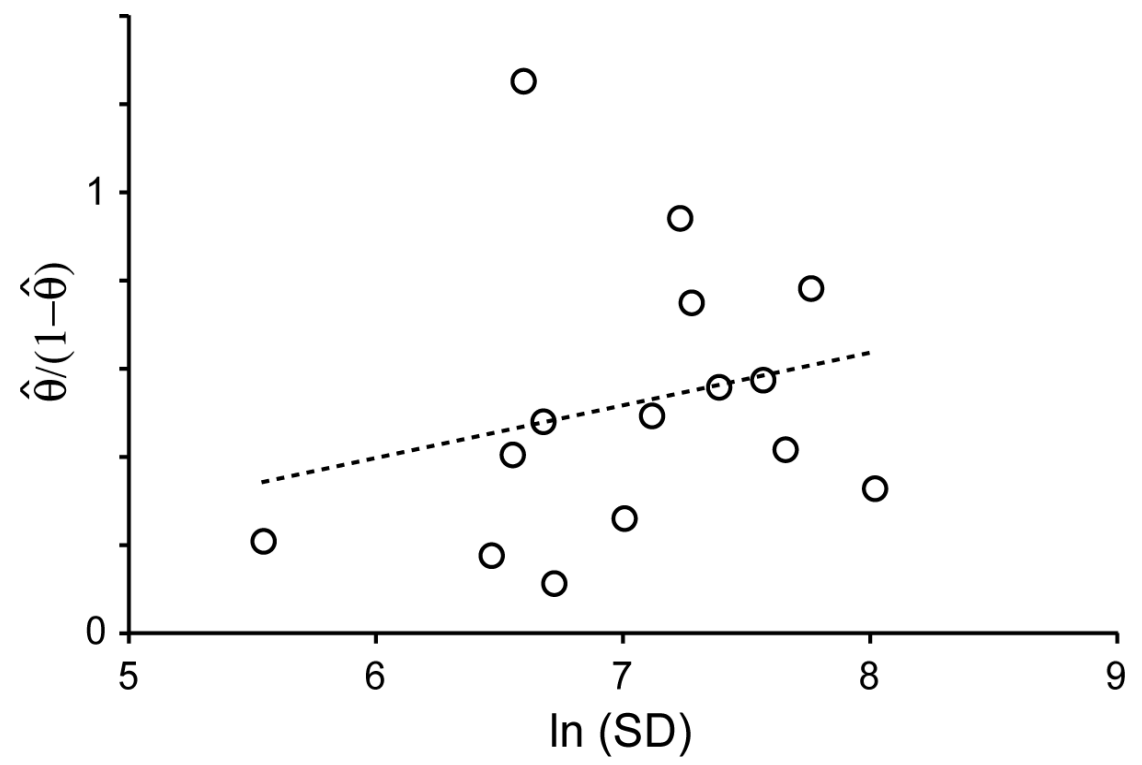

Fig. 3. Population genetic structure in Neotrygon kublii in the Indo-Malay-Papua archipelago. Pairwise multiple-locus estimates of genetic differentiation (ordinates) plotted against the logarithm of ship distance $\left(S D\right.$; abscissa). The regression equation was ${ }^{\wedge} \theta /\left(1-^{\wedge} \theta\right)=0.118$ $\ln (S D)-0.309$ [ $R^{2}=0.058$; Mantel's test (Belkhir et al., 2000): $\left.P=0.13\right]$. Pairwise multiplelocus $\theta$ were estimated from genotypic data (Supplementary material, Table S3) according to Weir and Cockerham (1984). 


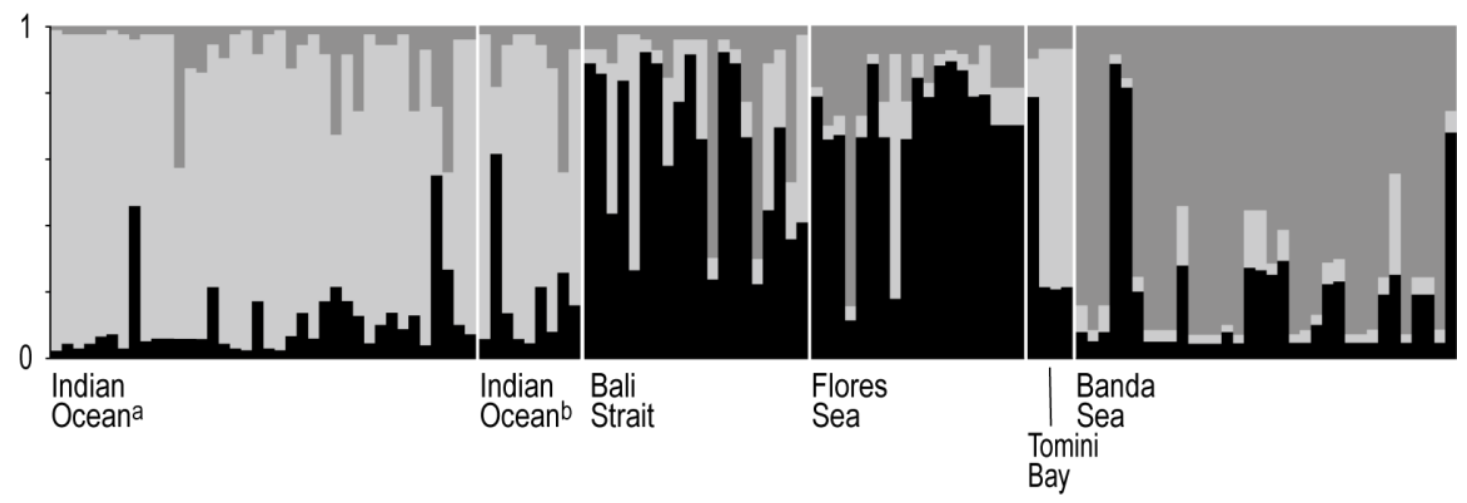

Fig. 4. Neotrygon kublii. Output of Bayesian structure analysis (STRUCTURE: Falush et al., 2007) with K=3 populations, on individual genotypes at 4 presumptive intron loci for 6 samples from the Indo-Malay-Papua archipelago (Supplementary material, Table S3). Individuals are represented by vertical bars; the different grey tones correspond to different genetic clusters and their proportion in an individual (ordinate) indicates its degree of assignment to the corresponding cluster. a Binuangen sample (Fig. 1); b Malang sample (Fig. 1). 


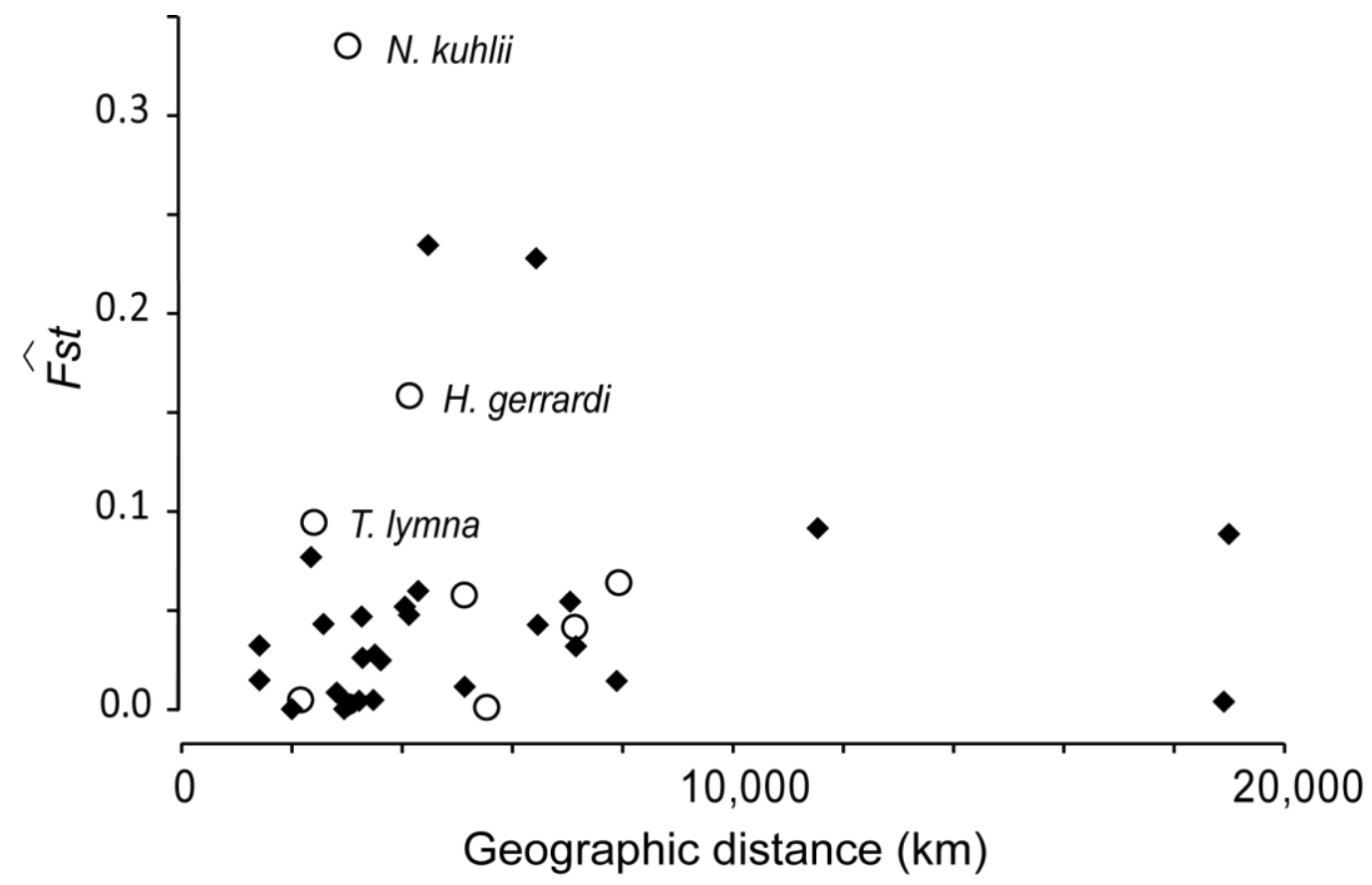

Fig. 5. Plot of genetic-differentiation estimates (overall ${ }^{\wedge} F$ st value) against geographic distance in coastal elasmobranchs and teleosts. Data from nuclear-marker based phylogeographic surveys of 8 coastal elasmobranch species (open circles) (Chevolot et al., 2006; Dudgeon et al., 2009; Plank et al., 2010; Ovenden et al., 2011; present study) and 27 coastal teleost fish species (black diamonds) (Blanquer et al., 1992; Kotoulas et al., 1995; Borsa et al., 1997a; Roldán et al., 1998; Hoarau et al., 2002; Planes and Fauvelot, 2002; Borsa, 2003; Rohfritsch and Borsa, 2005; Hemmer-Hansen et al., 2007; Rolland et al., 2007; Magsino and Juinio-Meñez, 2008; Matschiner et al., 2009; Puebla et al., 2009; Purcell et al., 2009; González-Wangüemert et al., 2010; Jones et al., 2010; McCusker and Bentzen, 2010; Mobley et al., 2010; Fauvelot and Borsa, 2011; Francisco et al., 2011; Gaither et al., 2011; Horne et al., 2011; Muths et al., 2011; Timm et al., 2012). Other details in Supplementary material, Table S7. 
Supplementary material to "Population genetic structure of the blue-spotted maskray Neotrygon kublii and two other Indo-West Pacific stingray species (Myliobatiformes: Dasyatidae), inferred from size-polymorphic intron markers” by Philippe Borsa, Irma S. Arlyza, Martin Laporte, and Patrick Berrebi

\section{Table S1}

Introns tested for size polymorphism in Himantura gerrardi, Neotrygon kublii, and Taeniura lymna. Intron no: assumed intron number in teleost fishes. Mendelian-like allele-size polymorphisms were detected using primer pairs (Act-2-F, Act-2-R), (Cam-3-F, Cam-3-R) and (CK6-5', CK7-3) in H. gerrardi, (Cam-3-F, Cam-3-R), (CK6-5, CK7-3) and (Gpd2F, Gpd3R) in N. kublii, and (Aldo3F, Aldo2R), (CK6-5', CK7-3) and (RPEX1F, RPEX2R) in Taeniura lymna. For the other primer pairs tested, either the DNA band patterns were not variable (thus exhibiting sample monomorphism), or they were variable but we failed to interpret them in terms of size polymorphism at Mendelian loci. In a few cases, the amplification was too weak for scoring, or the intensity of DNA bands was highly variable across individuals, or a substantial proportion of individuals could not be scored either because of bands that were too weak or because of overlapping bands presumably from other loci. Since a number of factors, e.g. unsuitable annealing temperature, quality of the primers, quality of the DNA extracts, etc. may lead to unsatisfactory results of this kind, we consider that more tests are needed before definitely discarding the primer pairs that failed to produce Mendelian-like polymorphisms in our study.

\begin{tabular}{|c|c|c|c|c|}
\hline $\begin{array}{l}\text { Gene or gene } \\
\text { family }\end{array}$ & $\begin{array}{l}\text { Intron } \\
\text { no. }\end{array}$ & $\begin{array}{l}\text { Abbrev- } \\
\text { iation }\end{array}$ & Primer pair & Reference \\
\hline Actin & 2 & Act-2 & Act-2-F, Act-2-R & Atarhouch et al. (2003) \\
\hline Aldolase B & 2 & AldoB2 & Aldob2F, Aldexon3R & Hassan et al. (2002) \\
\hline Aldolase B & 4 & AldoB4 & Aldo5F, Aldo3.1R & Hassan et al. (2002) \\
\hline Aldolase B & 5 & AldoB5 & Aldo3F, Aldo2R & Hassan et al. (2002) \\
\hline Aldolase C & 1 & AldoC1 & Aldoc1F, Aldoc2R & Hassan et al. (2002) \\
\hline$\alpha$-Amylase & 1 & $A m 2 B-1$ & $A m 2 b 1 F, A m 2 b 2 R$ & Hassan et al. (2002) \\
\hline$\alpha$-Amylase & 3 & $A m 2 B-3$ & $A m 2 b 3 F, A m 2 b 4 \mathrm{R}$ & Hassan et al. (2002) \\
\hline Calmodulin & 3 & Cam-3 & Cam-3-F, Cam-3-R & Atarhouch et al. (2003) \\
\hline Calmodulin & 4 & $C a M$ & CALMex4F, CALMex5R & Chow (1998); Chow and Takeyama (2000) \\
\hline Creatine kinase & 6 & $C K$ & CK6-5, CK7-3' & Palumbi et al. (1991) \\
\hline Creatine kinase & 7 & Ck7 & Ck7F, Ck8R & Hassan et al. (2002) \\
\hline $\begin{array}{l}\text { Glyceraldehyde-3-phosphate } \\
\text { dehydrogenase }\end{array}$ & 2 & $G p d 2$ & Gpd2F, Gpd3R & Hassan et al. (2002) \\
\hline $\begin{array}{l}\text { Gonadotropin-releasing } \\
\text { hormone } 3\end{array}$ & 3 & GnRH3-3 & GnRH3F, GnRH3R & Hassan et al. (2002) \\
\hline Growth hormone & 2 & Gh2 & Gh2F, Gh3R & Hassan et al. (2002) \\
\hline Growth hormone & 5 & Gh5 & Gh5F, Gh6R & Hassan et al. (2002) \\
\hline $\begin{array}{l}\text { Major histocomptability } \\
\text { complex class II antigen }\end{array}$ & 1 & MhcII & $M b c 1 F, M b c 2 R$ & Hassan et al. (2002) \\
\hline Myosin, light chain & 3 & Mlc-3 & $M l c-3-F, M l c-3-R$ & Atarhouch et al. (2003) \\
\hline Opsin & 1 & Ops-1 & Ops-1-F, Ops-1-R & Atarhouch et al. (2003) \\
\hline Ribosomal protein & 1 & $R P$ & RPEX1F, RPEX2R & Chow and Takeyama (1998) \\
\hline$\alpha$-Tropomyosin & 1 & $\operatorname{Tr} 1$ & $\operatorname{Tr} 1 F, \operatorname{Tr} 1 \mathrm{R}$ & Hassan et al. (2002) \\
\hline
\end{tabular}

References

Atarhouch, T., Rami, M., Cattaneo-Berrebi, G., Ibanez, C., Augros, S., Boissin, E., Dakkak, A., Berrebi, P., 2003. Biotechniques 35, 676-682.

Chow, S., 1998. Fisheries Sci. 64, 999-1000.

Chow, S., Hazama, K., 1998. Mol. Ecol. 7, 1255-1256.

Chow, S., Takeyama, H., 1998. Fisheries Sci. 64, 397-402.

Chow, S., Takeyama, H., 2000. J. Fish Biol. 56, 1087-1098.

Hassan, M., Lemaire, C., Fauvelot, C., Bonhomme, F., 2002. Mol. Ecol. Notes 2, 334-340.

Palumbi, S., Martin, A., Romano, S., McMillan, W.O., Stice, L., Grabowski, G., 1991. The simple fool's guide to PCR, v. 2.0. University of Hawai'i, Honolulu, $47 \mathrm{pp}$. 
Table S2

Individual genotypes in 5 Himantura gerrardi samples from the Indo-Malay-Papua archipelago, at 7 presumptive intron loci. Alleles at a locus are designated by their approximate size (in bp).

\begin{tabular}{|c|c|c|c|c|c|c|c|}
\hline \multirow{2}{*}{$\begin{array}{l}\text { Sample, } \\
\text { individual no. }\end{array}$} & \multicolumn{7}{|l|}{ Locus } \\
\hline & Act-2 & Cam-3 a & Cam-3 b & Cam-3c & Cam-3d & Cam-3e & $C K$ \\
\hline \multicolumn{8}{|l|}{ Indian Ocean } \\
\hline DY 1 & $225 / 210$ & - & 175 & 155 & - & 125 & 173 \\
\hline SY 1 & 238 & 200 & 175 & $155 / 152$ & 138 & 125 & 175 \\
\hline SY 2 & $238 / 225$ & - & 175 & 155 & - & 125 & - \\
\hline PLRQ 1 & 238 & 200 & 175 & 155 & $140 / 138$ & 125 & 175 \\
\hline PLRC 2 & 238 & $206 / 200$ & $175 / 173$ & 155 & 138 & 125 & - \\
\hline \multicolumn{8}{|l|}{ Java Sea } \\
\hline BT07 1 & $238 / 225$ & 203 & $175 / 173$ & $158 / 155$ & 140 & 125 & 175 \\
\hline ВT07 2 & $238 / 225$ & 200 & 175 & 155 & $140 / 138$ & 125 & $175 / 173$ \\
\hline ВТ07 3 & $238 / 225$ & $203 / 200$ & $175 / 173$ & $158 / 155$ & $140 / 138$ & 125 & $175 / 173$ \\
\hline BT07 4 & $238 / 225$ & $203 / 200$ & $175 / 173$ & $161 / 158$ & - & 125 & $175 / 173$ \\
\hline ВТ07 5 & 225 & $203 / 200$ & $175 / 173$ & $158 / 155$ & $140 / 138$ & 125 & $175 / 173$ \\
\hline BT07 6 & $238 / 225$ & $203 / 200$ & $175 / 173$ & 161 & 140 & 125 & 175 \\
\hline BT08 1 & 225 & $203 / 200$ & 175 & 155 & - & 125 & 175 \\
\hline BT08 2 & 225 & 200 & $175 / 173$ & $161 / 155$ & - & 125 & $175 / 173$ \\
\hline BT08 3 & 238 & 200 & $175 / 173$ & $158 / 155$ & - & 125 & $175 / 173$ \\
\hline BT08 4 & 238 & $203 / 200$ & $175 / 173$ & 155 & 140 & 125 & 175 \\
\hline BT08 5 & 238 & 200 & $175 / 173$ & 155 & 140 & 125 & - \\
\hline BT08 6 & $238 / 225$ & $203 / 200$ & $175 / 171$ & $158 / 155$ & 140 & 125 & $175 / 173$ \\
\hline BT08 7 & $238 / 225$ & $203 / 200$ & 175 & $161 / 155$ & - & $126 / 125$ & 0 \\
\hline BT08 8 & 238 & $203 / 200$ & $175 / 173$ & $158 / 155$ & - & 125 & $175 / 173$ \\
\hline BT08 9 & $238 / 225$ & $203 / 200$ & $175 / 173$ & $158 / 155$ & - & 125 & $175 / 173$ \\
\hline ВТ08 10 & 238 & $203 / 200$ & $175 / 173$ & $158 / 155$ & - & 125 & $175 / 173$ \\
\hline ВТ08 11 & 238 & $203 / 200$ & - & $158 / 155$ & - & 125 & $175 / 173$ \\
\hline ВT08 12 & $238 / 225$ & - & - & - & - & - & $175 / 173$ \\
\hline ВT08 13 & 238 & - & - & - & - & - & $175 / 173$ \\
\hline BT08 14 & $238 / 225$ & 200 & $175 / 173$ & $158 / 155$ & $140 / 138$ & 125 & $175 / 173$ \\
\hline BT08 15 & $238 / 225$ & 200 & $175 / 173$ & $158 / 155$ & 140 & 125 & 175 \\
\hline \multicolumn{8}{|l|}{ Unknown } \\
\hline BLTR 18 & $238 / 225$ & $206 / 200$ & $178 / 175$ & $158 / 155$ & $140 / 138$ & 125 & $175 / 173$ \\
\hline BLTR 19 & $238 / 225$ & $206 / 200$ & 175 & $158 / 155$ & 138 & 125 & $175 / 173$ \\
\hline BLTR 20 & $238 / 225$ & $206 / 200$ & 175 & $158 / 155$ & 138 & 125 & $175 / 173$ \\
\hline BLTR 21 & - & 200 & $175 / 171$ & - & $140 / 136$ & 127 & 173 \\
\hline BLTR 22 & $238 / 225$ & $206 / 200$ & $175 / 171$ & $158 / 155$ & $138 / 136$ & 125 & 175 \\
\hline BLTR 23 & $238 / 225$ & $206 / 200$ & 175 & 158 & 138 & 125 & $175 / 173$ \\
\hline BLTR 24 & $238 / 225$ & 200 & $173 / 171$ & $155 / 152$ & $138 / 136$ & $127 / 125$ & $175 / 173$ \\
\hline BLTR 25 & $238 / 225$ & $206 / 200$ & $178 / 175$ & $158 / 155$ & $140 / 138$ & 125 & $175 / 173$ \\
\hline BLTR 26 & 238 & $206 / 200$ & $178 / 175$ & $161 / 155$ & 138 & 125 & 175 \\
\hline \multicolumn{8}{|l|}{ Sunda Strait } \\
\hline LBN 1 & $238 / 225$ & 200 & $175 / 173$ & $158 / 155$ & 140 & 125 & $175 / 173$ \\
\hline LBN 2 & $238 / 225$ & $203 / 200$ & $175 / 173$ & 155 & 140 & 125 & $175 / 173$ \\
\hline LBN 3 & $238 / 225$ & 200 & $175 / 173$ & $158 / 155$ & 138 & 125 & $175 / 173$ \\
\hline LBN 4 & 238 & 200 & 175 & 158/155 & $140 / 138$ & 125 & 175 \\
\hline LBN 5 & $238 / 225$ & 200 & $175 / 173$ & $158 / 155$ & $140 / 138$ & 125 & $175 / 173$ \\
\hline LBN 6 & 238 & 200 & 175 & $158 / 155$ & 140 & 125 & $175 / 173$ \\
\hline LBN 7 & 225 & 200 & 175 & $158 / 155$ & 140 & 125 & 175 \\
\hline \multicolumn{8}{|l|}{ West Papua } \\
\hline HNSM1 & - & - & 171 & 155 & - & 125 & 175 \\
\hline HNSM2 & - & - & - & 155 & - & 125 & 175 \\
\hline
\end{tabular}


Table S3

Individual genotypes in 6 Neotrygon kublii samples from the Indo-Malay-Papua archipelago, at 4 presumptive intron loci. Alleles at a locus are designated by their approximate size (in bp).

\begin{tabular}{|c|c|c|c|c|c|c|c|c|c|}
\hline \multirow{3}{*}{$\begin{array}{l}\text { Sample, } \\
\quad \text { individual no. } \\
\text { Indian Ocean }{ }^{\mathrm{a}}\end{array}$} & \multicolumn{4}{|l|}{ Locus } & \multicolumn{5}{|c|}{$\begin{array}{ll}\text { Sample, } & \text { Locus }\end{array}$} \\
\hline & Cam-3 fast & Cam-3 slow & $C K$ & Gpd2 & individual no. & Cam-3 fast & Cam-3 slow & $C K$ & $G p d 2$ \\
\hline & & & & & MB18 & $300 / 282$ & $400 / 370$ & $363 / 361$ & 167 \\
\hline BNG1 & 282 & 400 & 368 & 167 & MB19 & $300 / 282$ & 400 & 361 & - \\
\hline BNG2 & $282 / 264$ & 400 & $368 / 361$ & 167 & MB20 & 282 & 400 & $366 / 361$ & 167 \\
\hline BNG4 & $282 / 264$ & 400 & $363 / 361$ & 167 & Flores Sea & & & & \\
\hline BNG5 & $282 / 264$ & 400 & $368 / 363$ & 167 & LB1 & 300 & 400 & 361 & $173 / 167$ \\
\hline BNG7 & $282 / 264$ & 400 & 363 & 167 & LB2 & 300 & 400 & 361 & $169 / 167$ \\
\hline BNG8 & 282 & 400 & 363 & 167 & LB3 & 300 & $400 / 370$ & $363 / 361$ & tr \\
\hline BNG9 & 282 & $400 / 370$ & 368 & 167 & LB4 & 300 & 400 & $361 / 359$ & - \\
\hline BNG10 & 282 & 400 & $368 / 363$ & 167 & LB5 & 300 & 400 & 361 & 167 \\
\hline BNG11 & 282 & $400 / 370$ & 361 & 167 & LB6 & 300 & $400 / 370$ & 361 & $173 / 167$ \\
\hline BNG12 & - & - & 368 & - & LB7 & 300 & 400 & $363 / 361$ & 167 \\
\hline BNG13 & 282 & 400 & $368 / 361$ & 167 & LB8 & $300 / 282$ & 400 & $368 / 361$ & 167 \\
\hline BNG14 & 282 & 400 & 363 & 167 & LB9 & 300 & 400 & $363 / 361$ & 167 \\
\hline BNG15 & 282 & 400 & 363 & 167 & LB10 & 300 & $400 / 370$ & $363 / 361$ & 167 \\
\hline BNG16 & $300 / 282$ & 400 & $368 / 363$ & 164 & LB11 & 300 & 400 & 361 & $173 / 167$ \\
\hline BNG17 & $300 / 282$ & 400 & 368 & $167 / 164$ & LB12 & 300 & $400 / 385$ & 361 & 167 \\
\hline BNG18 & $300 / 282$ & 400 & 368 & $167 / 164$ & LB13 & 300 & $400 / 385$ & $363 / 361$ & $173 / 167$ \\
\hline BNG19 & 282 & 400 & 361 & 167 & LB14 & 300 & $400 / 385$ & $363 / 361$ & 167 \\
\hline BNG20 & $282 / 264$ & 400 & $368 / 361$ & $167 / 164$ & LB15 & $300 / 282$ & 400 & 361 & $173 / 167$ \\
\hline BNG21 & 282 & 400 & $368 / 363$ & 167 & LB16 & - & $400 / 385$ & $363 / 361$ & 167 \\
\hline BNG22 & 282 & 400 & 368 & 167 & LB17 & 300 & 400 & - & 167 \\
\hline BNG23 & $300 / 282$ & 400 & $368 / 361$ & 167 & LB18 & 300 & 400 & - & 167 \\
\hline BNG24 & 282 & 400 & $368 / 363$ & 167 & LB19 & 300 & 400 & - & 167 \\
\hline BNG25 & 282 & 400 & 368 & 167 & Tomini Bay & & & & \\
\hline BNG26 & $300 / 282$ & 400 & 368 & $167 / 164$ & LPPS1 & - & - & 361 & 167 \\
\hline BNG27 & 282 & 400 & $368 / 366$ & $167 / 164$ & LPPS2 & 282 & 400 & 361 & 167 \\
\hline BNG28 & 282 & 400 & 363 & 167 & LPPS3 & 282 & 400 & 361 & 167 \\
\hline BNG29 & $300 / 282$ & 400 & $368 / 361$ & 167 & LPPS4 & 282 & 400 & 361 & 167 \\
\hline BNG30 & $300 / 282$ & 400 & 363 & $167 / 164$ & Banda Sea & & & & \\
\hline BNG31 & $300 / 282$ & 400 & $368 / 361$ & 167 & KDI4 & - & $430 / 400$ & - & - \\
\hline BNG32 & $300 / 282$ & 400 & $368 / 361$ & $167 / 164$ & KDI5 & $300 / 282$ & 400 & 361 & 164 \\
\hline BNG33 & $282 / 264$ & 400 & $368 / 361$ & 167 & KDI6 & 300 & 400 & $363 / 361$ & 164 \\
\hline BNG34 & $300 / 282$ & 400 & $368 / 363$ & 167 & KDI7 & $300 / 282$ & 400 & 361 & 164 \\
\hline BNG35 & 282 & 400 & $368 / 366$ & $167 / 164$ & KDI8 & 300 & $400 / 370$ & 366 & $167 / 164$ \\
\hline BNG36 & 282 & 400 & - & 167 & KDI9 & 300 & $400 / 370$ & $366 / 361$ & $167 / 164$ \\
\hline BNG37 & $300 / 282$ & 400 & $368 / 361$ & $167 / 164$ & KDI10 & 300 & 年 & - & 然 \\
\hline BNG38 & 282 & 400 & $368 / 363$ & $167 / 164$ & KDI11 & 300 & 400 & 361 & $167 / 164$ \\
\hline BNG39 & $300 / 282$ & $400 / 370$ & $363 / 361$ & $167 / 164$ & KDI12 & 300 & 400 & $363 / 361$ & 164 \\
\hline BNG40 & $300 / 282$ & 400 & $363 / 361$ & $167 / 164$ & KDI13 & 300 & 400 & $363 / 361$ & 164 \\
\hline BNG41 & 282 & 400 & $363 / 361$ & 167 & KDI14 & 300 & 400 & $363 / 361$ & 164 \\
\hline BNG42 & $300 / 282$ & 400 & 368 & 167 & KDI15 & 300 & 400 & - & - \\
\hline Indian Ocean b & & & & & KDI16 & $300 / 282$ & 400 & 361 & $167 / 164$ \\
\hline SB1 & 282 & 400 & 363 & 167 & KDI17 & 300 & 400 & 361 & 164 \\
\hline SB2 & 300 & 400 & 363 & 167 & KDI18 & 300 & 400 & 361 & 164 \\
\hline SB3 & $282 / 264$ & 400 & 361 & 167 & KDI19 & 300 & 400 & 361 & 164 \\
\hline SB4 & 282 & 400 & 363 & 167 & KDI20 & 300 & $430 / 400$ & $361 / 359$ & 164 \\
\hline SB5 & $282 / 264$ & 400 & 363 & 167 & KDI21 & 300 & 430 & - & - \\
\hline SB6 & 282 & 400 & 361 & 167 & KDI22 & 300 & 400 & 361 & 164 \\
\hline SB7 & $282 / 264$ & 400 & $363 / 361$ & $167 / 164$ & KDI23 & $300 / 282$ & 400 & 361 & $167 / 164$ \\
\hline SB8 & $300 / 282$ & 400 & $363 / 361$ & $167 / 164$ & KDI24 & $300 / 282$ & 400 & - & - \\
\hline SB9 & 264 & $400 / 370$ & 363 & $167 / 164$ & KDI25 & $300 / 282$ & 400 & 361 & $167 / 164$ \\
\hline Bali Strait & & & & & KDI26 & 300 & 400 & 361 & - \\
\hline MB1 & 300 & 400 & $366 / 361$ & 167 & KDI27 & $300 / 282$ & $400 / 370$ & 361 & 164 \\
\hline MB2 & $300 / 282$ & $400 / 370$ & 366 & $167 / 164$ & KDI28 & 300 & 400 & 361 & 164 \\
\hline MB3 & $300 / 282$ & 400 & $363 / 361$ & 167 & KDI29 & 300 & 400 & $363 / 361$ & 164 \\
\hline MB4 & $300 / 282$ & 400 & 366 & 167 & KDI30 & 300 & 400 & 359 & - \\
\hline MB5 & 282 & 400 & $366 / 363$ & 167 & KDI31 & 300 & 400 & $363 / 361$ & $167 / 164$ \\
\hline MB6 & 300 & 400 & 366 & 167 & KDI32 & 300 & 400 & $363 / 361$ & $167 / 164$ \\
\hline MB7 & 300 & 400 & $366 / 361$ & 167 & KDI33 & 300 & 400 & 361 & 164 \\
\hline MB8 & $300 / 282$ & 400 & $366 / 363$ & $167 / 164$ & KDI34 & 300 & 400 & 361 & 164 \\
\hline MB9 & $300 / 282$ & 400 & $366 / 361$ & 167 & KDI35 & 300 & 400 & $363 / 361$ & 164 \\
\hline MB10 & 300 & $400 / 370$ & $366 / 363$ & 167 & KDI36 & 300 & 400 & 361 & $167 / 164$ \\
\hline MB11 & $300 / 282$ & 400 & $366 / 363$ & 167 & KDI37 & $300 / 282$ & 400 & $363 / 361$ & $167 / 164$ \\
\hline MB12 & 300 & 400 & $363 / 361$ & $167 / 164$ & KDI38 & 300 & 400 & $363 / 359$ & 164 \\
\hline MB13 & 300 & 400 & 366 & 167 & KDI39 & 300 & 400 & 361 & $167 / 164$ \\
\hline MB14 & 300 & 400 & $366 / 361$ & 167 & KDI40 & 300 & 400 & 361 & $167 / 164$ \\
\hline MB15 & 300 & 400 & $363 / 361$ & 167 & KDI41 & 300 & 400 & $363 / 361$ & 164 \\
\hline MB16 & 300 & 400 & $363 / 361$ & $167 / 164$ & KDI42 & 300 & 400 & 361 & 167 \\
\hline MB17 & $300 / 282$ & 400 & $363 / 361$ & 167 & KDI43 & $300 / 282$ & - & - & $167 / 164$ \\
\hline
\end{tabular}

a Binuangen sample (Fig. 1A); b Malang sample (Fig. 1A) 
Table S4

Individual genotypes in three Taeniura lymna samples from the Indo-Malay-Papua archipelago, at 5 presumptive intron loci. Alleles at a locus are designated by their approximate size (in bp).

\begin{tabular}{|c|c|c|c|c|c|}
\hline \multirow{2}{*}{$\begin{array}{l}\text { Sample, } \\
\quad \text { individual no. }\end{array}$} & \multicolumn{5}{|l|}{ Locus } \\
\hline & AldoB5 slow & AldoB5 fast & AldoB5 faster & $C K$ & $R P$ \\
\hline \multicolumn{6}{|l|}{ Java Sea } \\
\hline KS 1 & 280 & $123 / 119$ & 085 & $138 / 133$ & 290 \\
\hline KS 2 & $284 / 280$ & $123 / 119$ & 085 & 133 & 290 \\
\hline KS 3 & 280 & 123 & $087 / 085$ & 133 & 296 \\
\hline KS 4 & 280 & 123/119 & $087 / 085$ & $138 / 133$ & 290 \\
\hline KS 5 & 284 & $123 / 119$ & $087 / 085$ & 133 & 290 \\
\hline KS 6 & 280 & 119 & 085 & 133 & 290 \\
\hline KS 7 & 280 & 123 & 087/085 & 138 & $296 / 290$ \\
\hline \multicolumn{6}{|l|}{ Flores Sea } \\
\hline LB 1 & 280 & $123 / 119$ & 085 & 133 & 290 \\
\hline LB 2 & $284 / 280$ & 119 & 085 & 133 & 290 \\
\hline LB 3 & 284 & 119 & 087 & 133 & $296 / 290$ \\
\hline LB 4 & 284 & 119 & 085 & 133 & 290 \\
\hline LB 5 & $284 / 280$ & 119 & 085 & 133 & 290 \\
\hline LB 6 & $284 / 280$ & 119 & 085 & 133 & 296 \\
\hline LB 7 & 284 & 119 & 085 & 133 & $296 / 290$ \\
\hline LB 8 & $284 / 280$ & 119 & 085 & 133 & 290 \\
\hline LB 9 & 280 & 119 & 085 & 133 & $313 / 290$ \\
\hline LB 10 & 280 & 119 & 085 & 133 & $313 / 290$ \\
\hline LB 11 & 280 & 119 & $087 / 085$ & 133 & 290 \\
\hline LB 12 & $284 / 280$ & $123 / 119$ & 085 & 133 & 290 \\
\hline \multicolumn{6}{|l|}{ Molucca Sea } \\
\hline LSNS 1 & 284 & - & 085 & - & - \\
\hline LSNS 2 & $284 / 280$ & - & 085 & - & - \\
\hline LSNS 3 & 280 & 123/119 & $087 / 085$ & 133 & - \\
\hline LSNS 4 & $284 / 280$ & 119 & 085 & 133 & 290 \\
\hline LSNS 5 & $284 / 280$ & 119 & 085 & 133 & 290 \\
\hline LSNS 6 & $284 / 280$ & 119 & 085 & 133 & 290 \\
\hline LSNS 7 & 280 & $123 / 119$ & 087/085 & 133 & 290 \\
\hline LSNS 8 & 280 & $123 / 119$ & 087/085 & 133 & 290 \\
\hline LSNS 9 & 280 & $123 / 119$ & $087 / 085$ & 133 & 290 \\
\hline LSNS 10 & 284 & 119 & 085 & 133 & 290 \\
\hline LSNS 11 & 280 & 119 & 085 & 133 & 290 \\
\hline LSNS 12 & $284 / 280$ & 119 & 085 & 133 & 290 \\
\hline LSNS 13 & 280 & 119 & 085 & 133 & 290 \\
\hline LSNS 14 & 284 & 119 & 085 & 133 & 290 \\
\hline
\end{tabular}


Table S5

Locus-pairwise linkage disequilibrium values (R: Belkhir et al., 2000) in samples of three stingray species from the Indo-Malay-Papuan archipelago. Probability of encountering a value equal or higher than the observed value under the null hypothesis $(P)$ is given (in brackets) when $P \leq 0.050$. Only one $P$-value remained significant after correction for multiple tests (Rice, 1989). A. Himantura gerrardi. Sample "Unknown" exhibited significant $D$ values (before correction for multiple tests) in 7/21 pairwise comparisons, which we interpret as linkage disequilibrium in the sample, due to admixture of individuals from different locations. B. Neotrygon kublii. One $R$ value remained significant after correction for multiple tests: sample 'Banda Sea' at locus pair (Cam-3 slow, CK). C. Taeniura lymna. $3 / 3$ D-values significant (before correction for multiple tests) in sample 'Molucca Sea': this may be ascribed to admixture.

\begin{tabular}{|c|c|c|c|c|c|c|c|}
\hline \multirow{2}{*}{ Locus } & \multirow{2}{*}{ Sample } & \multicolumn{6}{|l|}{ Locus } \\
\hline & & Cam-3 a & Cam-3 b & $\mathrm{Cam}_{-3} \mathrm{c}$ & Cam-3d & Cam-3e & $C K$ \\
\hline \multirow[t]{5}{*}{ Act-2 } & Indian Ocean & & 0.434 & 0.434 & & . & 0 \\
\hline & Java Sea & 0.032 & 0.228 & 0.189 & 0.590 & 0.058 & 0.149 \\
\hline & Sunda Strait & 0.107 & 0.301 & 0.107 & 0.153 & - & 0.165 \\
\hline & West Papua & & & & & & \\
\hline & Unknown & 0.163 & 0.294 & 0.946 & 0.313 & 0.163 & 0.748 \\
\hline \multirow[t]{4}{*}{ Cam-3 a } & $\begin{array}{l}\text { Indian Ocean } \\
\text { Java Sea }\end{array}$ & & $\overline{0} .125$ & $\begin{array}{l}0 \\
0.193\end{array}$ & $\begin{array}{l}0 \\
0.283\end{array}$ & $\overline{0} 119$ & $\overline{0}, 296$ \\
\hline & Sunda Strait & & 0.852 & 1.000 & 0.374 & -0.117 & 0.301 \\
\hline & West Papua & & & & & & \\
\hline & Unknown & & 0.158 & 0.946 & 0.673 & $1.000(P=0.016)$ & 0.649 \\
\hline \multirow{4}{*}{ Cam-3 b } & $\begin{array}{l}\text { Indian Ocean } \\
\text { Java Sea }\end{array}$ & & & $\begin{array}{l}0.313 \\
0.271\end{array}$ & 0.296 & $\overline{0} .391$ & $\overline{0} .296$ \\
\hline & Sunda Strait & & & 0.412 & 0.330 & - & 0.301 \\
\hline & West Papua & & & & & & \\
\hline & Unknown & & & $0.695(P=0.039)$ & $0.748(P=0.049)$ & $0.550(P=0.013)$ & 0.649 \\
\hline \multirow{4}{*}{ Cam-3c } & Indian Ocean & & & & & - & 0 \\
\hline & $\begin{array}{l}\text { Java Sea } \\
\text { Sunda Strait }\end{array}$ & & & & $\begin{array}{l}0.221 \\
0.374\end{array}$ & 0.240 & 0.288 \\
\hline & West Papua & & & & & & \\
\hline & Unknown & & & & 0.355 & $0.946(P=0.019)$ & 0.446 \\
\hline \multirow[t]{5}{*}{ Cam-3d } & Indian Ocean & & & & & & \\
\hline & Java Sea & & & & & - & 0.900 \\
\hline & Sunda Strait & & & & & - & 0.072 \\
\hline & West Papua & & & & & & \\
\hline & Unknown & & & & & $0.723(P=0.004)$ & 0.465 \\
\hline \multirow[t]{4}{*}{ Cam-3e } & Indian Ocean & & & & & & \\
\hline & Java Sea & & & & & & \\
\hline & Sunda Strait & & & & & & - \\
\hline & $\begin{array}{l}\text { West Papua } \\
\text { Unknown }\end{array}$ & & & & & & $\overline{0} .772(P=0.018)$ \\
\hline \multicolumn{8}{|l|}{ B } \\
\hline \multirow[t]{2}{*}{ Locus } & \multirow[t]{2}{*}{ Sample } & & \multicolumn{5}{|l|}{ Locus } \\
\hline & & & \multirow{2}{*}{\multicolumn{2}{|c|}{ Cam-3 slow }} & & \multirow{2}{*}{\multicolumn{2}{|c|}{$G p d 2$}} \\
\hline \multirow{6}{*}{ Cam-3 fast } & \multirow{2}{*}{\multicolumn{2}{|c|}{ Indian Ocean ${ }^{a}$}} & & & $\begin{array}{l}C K \\
0.136\end{array}$ & & \\
\hline & & & $0.607(P=0.031)$ & & 95 & 0.349 & \\
\hline & \multicolumn{2}{|l|}{$\begin{array}{l}\text { Indian Ucean' } \\
\text { Bali Strait }\end{array}$} & 0.011 & & 50 & 0.108 & \\
\hline & Flores Sea & & 0.200 & & $42(P=0.044)$ & 0.124 & \\
\hline & Tomini Bay & & & & & & \\
\hline & Banda Sea & & 0.085 & & 99 & 0.179 & \\
\hline Cam-3 slow & Indian Ocean a & & & & 46 & 0.020 & \\
\hline & Indian Ocean b & & & & 25 & 0.563 & \\
\hline & Bali Strait & & & & 62 & 0.138 & \\
\hline & Flores Sea & & & & 42 & 0.114 & \\
\hline & Tomini Bay & & & & & & \\
\hline & Banda Sea & & & & $06(P=0.0001)$ & 0.109 & \\
\hline$C K$ & Indian Ocean a & & & & & 0.138 & \\
\hline & Indian Ocean ${ }^{b}$ & & & & & & \\
\hline & Bali Strait & & & & & 0.148 & \\
\hline & Flores Sea & & & & & 0.354 & \\
\hline & Tomini Bay & & & & & & \\
\hline & Banda Sea & & & & & 0.196 & \\
\hline
\end{tabular}

\begin{tabular}{|c|c|c|c|c|c|}
\hline \multicolumn{6}{|l|}{ C } \\
\hline \multirow[t]{2}{*}{ Locus } & \multirow[t]{2}{*}{ Sample } & Locus & & & \\
\hline & & AldoB5 fast & AldoB5 faster & $C K$ & $\mathrm{RP}$ \\
\hline \multirow[t]{3}{*}{ AldoB5 slow } & Java Sea & 0.153 & 0.132 & $0.538(P=0.041)$ & 0.404 \\
\hline & Flores Sea & 0.268 & 0.252 & - & $0.395(P=0.026)$ \\
\hline & Molucca Sea & $0.690(P=0.017)$ & $0.693(P=0.008)$ & - & - \\
\hline \multirow[t]{3}{*}{ AldoB5 fast } & Java Sea & & 0.753 & 0.511 & $0.920(P=0.005)$ \\
\hline & Flores Sea & & 0.205 & - & 0.287 \\
\hline & Molucca Sea & & $1.000(P=0.003)$ & - & - \\
\hline \multirow[t]{3}{*}{ AldoB5 faster } & Java Sea & & & 0.330 & 0.594 \\
\hline & Flores Sea & & & - & 0.190 \\
\hline & Molucca Sea & & & - & - \\
\hline \multirow[t]{3}{*}{$C K$} & Java Sea & & & & 0.090 \\
\hline & Flores Sea & & & & - \\
\hline & Molucca Sea & & & & - \\
\hline
\end{tabular}

References:

Belkhir, K., Borsa, P., Chikhi, L., Raufaste, N., Bonhomme, F., 2000. http://www.genetix.univ-montp2.fr/genetix/.

Rice, W.R., 1989. Evolution 43, 223-225. 
Table S6

Neotrygon kublii. Output of Bayesian structure analysis (STRUCTURE: Falush et al., 2007) run with K=2-6 populations, on individual genotypes at 4 presumptive intron loci for 6 samples from the Indo-Malay-Papua archipelago (Supplementary material, Table S3). Individuals are represented by vertical bars; the different grey colours correspond to different genetic clusters and their proportion in an individual (ordinate) indicates its degree of assignment to the corresponding cluster. Visual observation of the graphs indicates that maximum segregation of the total sample into different clusters was reached with $K=3$. Prob. Posterior probability of assignment of a given individual to a cluster. Individuals grouped by sample. Samples separated by vertical traits.
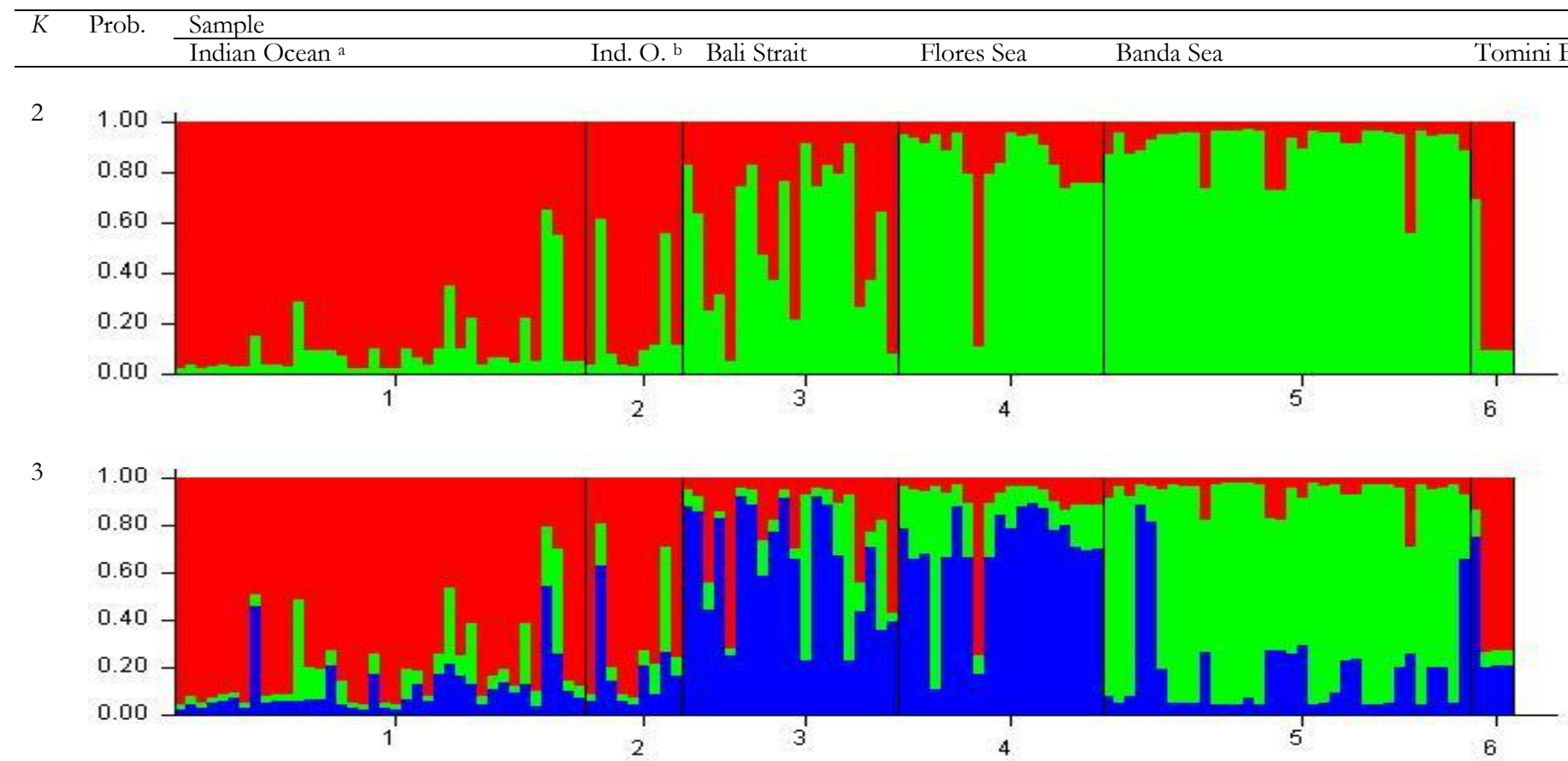

4
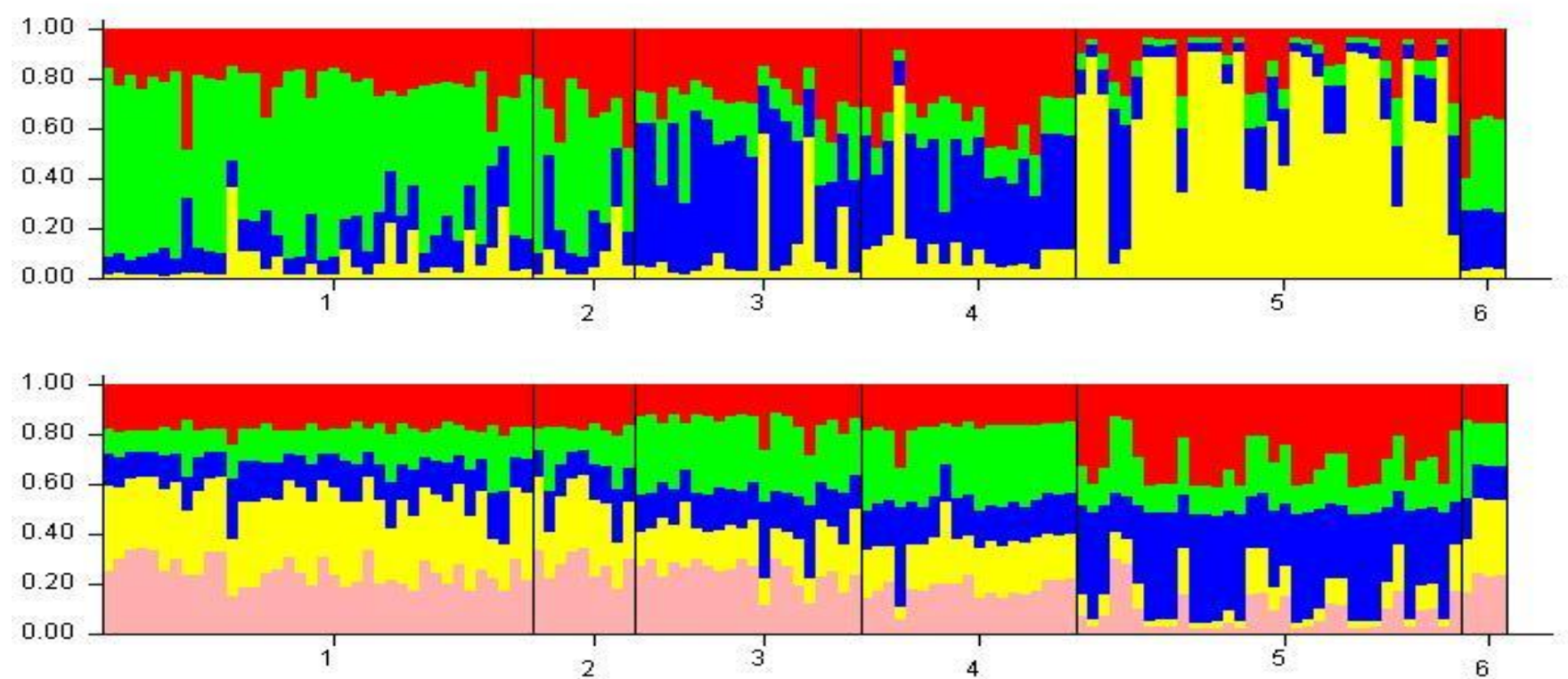

$6 \quad 1.00$

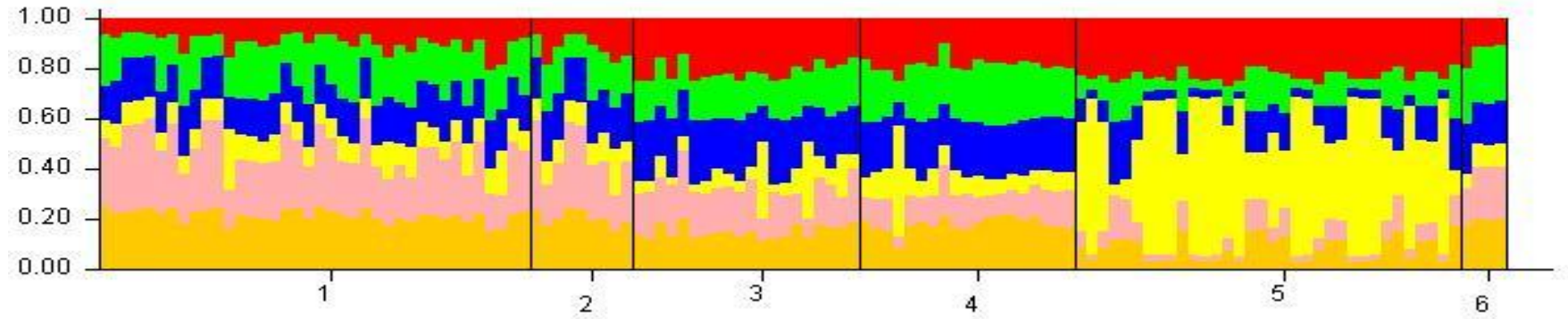

${ }^{a}$ Binuangen sample (Fig. 1A); b Malang sample (Fig. 1A)

Reference:

Falush, D., Stephens, M., Pritchard, J., 2007. Mol. Ecol. Resour. 7, 574-578. 
Table S7

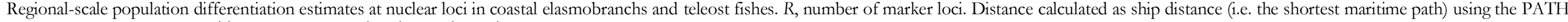
menu of Google Earth (http://www.google.co.uk/intl/en_uk/earth/)

\begin{tabular}{|c|c|c|c|c|c|c|c|}
\hline \multicolumn{2}{|l|}{ Species } & \multirow[t]{2}{*}{ Genetic markers } & \multirow[t]{2}{*}{$r$} & \multirow[t]{2}{*}{ Geographical range considered } & \multirow{2}{*}{$\begin{array}{l}\text { Max. distance } \\
\text { between } \\
\text { samples }(\mathrm{km})\end{array}$} & \multirow{2}{*}{$\begin{array}{l}\text { Overall (max.) } \wedge^{\wedge} F_{s t} \\
\text { or equivalent }\end{array}$} & \multirow[t]{2}{*}{ Reference } \\
\hline Scientific name & Vernacular name & & & & & & \\
\hline \multicolumn{8}{|l|}{ Elasmobranchs } \\
\hline Himantura gerrardi & Sharpnose stingray & introns & 7 & Indo-Malay-Papua archipelago & 4130 & $0.159(0.493)$ & present study \\
\hline Neotrygon kublii & Blue-spotted maskray & introns & 4 & Indo-Malay archipelago & 3020 & $0.336(0.557)$ & present study \\
\hline Raja clavata & Thornback ray & microsatellites & 5 & NE Atlantic + Mediterranean & 7130 & $0.042(0.231)$ & Chevolot et al. (2006) \\
\hline Rhizoprionodon acutus & Milk shark & microsatellites & 6 & Indonesia and eastern Australia & 5130 & $0.058(0.223)$ & Ovenden et al. (2011) \\
\hline Sphyrna lewini & Scalloped hammerhead & microsatellites & 8 & Indonesia and eastern Australia & 5540 & $0.002(0.007)$ & Ovenden et al. (2011) \\
\hline Stegostoma fasciatum & Zebra shark & microsatellites & 13 & Central Indo W Pacific & 7940 & $0.065(0.098)$ & Dudgeon et al. (2009) \\
\hline Taeniura lymna & Ribbontail stingray & introns & 5 & Indo-Malay archipelago & 2410 & $0.095(0.153)$ & present study \\
\hline Urobatis halleri & Round stingray & microsatellites & 7 & California + Gulf of California & 2170 & $0.002-0.007(0.025)$ & Plank et al. (2010) \\
\hline \multicolumn{8}{|l|}{ Teleosts } \\
\hline Acanthurus triostegus & Manini & allozymes & 12 & W Pacific & 11540 a & $0.092(0.096)^{\text {a }}$ & Planes and Fauvelot (2002) \\
\hline Amphiprion ocellaris & False clownfish & microsatellites & 6 & Indo-Malay-Papua archipelago & 4120 & $0.048(0.208)$ & Timm et al. (2012) \\
\hline Anarbichas lupus & Atlantic wolffish & microsatellites & 12 & N Atlantic & 5140 & $0.012(0.037)$ & McCusker and Bentzen (2010) \\
\hline Cephalopholis argus & Peacock grouper & introns & 2 & Indo-West Pacific & 18970 & $0.089(0.496)$ & Gaither et al. (2011) \\
\hline Decapterus macrosoma & Round scad mackerel & intron & 1 & Indo-Malay archipelago & 3490 & $0.005(0.100)$ & Borsa (2003) \\
\hline Decapterus russelli & Indian scad mackerel & introns & 2 & Indo-Malay-Papua archipelago & 4280 & $0.061(0.165)$ & Rohfritsch and Borsa (2005) \\
\hline Diplodus sargus & White seabream & microsatellites & 9 & NE Atlantic + Mediterranean & 3540 & $0.029(0.115)$ & González-Wangüemert et al. (2010) \\
\hline Eleutheronema tetradactylum & Fourfinger threadfin & microsatellites & 5 & Northern Australia & 4480 & $0.235(0.581)$ & Horne et al. (2011) \\
\hline Gobionotothen gibberifrons & Humped rockcod & microsatellites & 8 & SW Atlantic & 2000 & $0.001(0.005)$ & Matschiner et al. (2009) \\
\hline Hypoplectrus puella & Barred hamlet & microsatellites & 10 & Gulf of Mexico & 3200 & $0.005(0.017)$ & Puebla et al. (2009) \\
\hline Lipophrys pholis & Shanny & intron & 1 & NE Atlantic + Mediterranean & 2940 & $0.000(0.048)$ & Francisco et al. (2011) \\
\hline Lutjanus kasmira & Common bluestripe snapper & introns & 2 & Indo-West Pacific & 18900 b & $0.004(0.048) \mathrm{b}$ & Gaither et al. (2010) \\
\hline Merluccius merluccius & Hake & allozymes & 10 & NE Atlantic + Mediterranean & 7170 & $0.033(0.052)$ & Roldán et al. (1998) \\
\hline Myripristis berndti & Blotcheye soldierfish & microsatellites & 8 & SW Indian Ocean & 2580 & $0.043(0.119)$ & Muths et al. (2011) \\
\hline Platichthys flesus & Flounder & allozymes & 5 & NE Atlantic & 3260 & $0.047 \pm 0.016(0.058)$ & Borsa et al. (1997) \\
\hline Platichthys flesus & Flounder & microsatellites & 9 & NE Atlantic & 3640 & $0.024(0.091)$ & Hemmer-Hansen et al. (2007) \\
\hline Pleuronectes platessa & Plaice & microsatellites & 6 & NE Atlantic & 2840 & $0.009(0.046)$ & Hoarau et al. (2002) \\
\hline Pomacentrus amboinensis & Ambon damselfish & microsatellites & 9 & Coral Sea to Bismarck Sea & 2360 & $0.077(0.214)$ & Jones et al. (2010) \\
\hline Psetta maxima & Turbot & allozymes & 5 & NE Atlantic + Mediterranean & 7050 & $0.055(0.101)$ & Blanquer et al. (1992) \\
\hline Scomberomorus commerson & Narrow-barred Spanish mackerel & microsatellites & 8 & Central Indo-West Pacific & 6450 & $0.228(0.311)$ & Fauvelot and Borsa (2011) \\
\hline Scopbthalmus rbombus & Brill & allozymes & 7 & NE Atlantic + Mediterranean & 4050 & $0.053(0.084)$ & Blanquer et al. (1992) \\
\hline Siganus argenteus & Forktail rabbitfish & allozymes & 14 & Eastern Philippines & 1420 & 0.015 & Magsino and Juinio-Meñez (2008) \\
\hline Siganus fuscescens & Mottled rabbitfish & allozymes & 9 & Eastern Philippines & 1420 & $0.033(0.081)$ & Magsino and Juinio-Meñez (2008) \\
\hline Solea solea & Common sole & allozymes & 12 & NE Atlantic + Mediterranean & 7900 & $0.015 \pm 0.003(0.126)$ & Kotoulas et al. (1995) \\
\hline Solea solea & Common sole & introns & 3 & NE Atlantic + Mediterranean & 6460 & $0.043(0.176)$ & Rolland et al. (2007) \\
\hline Stegastes partitus & Bicolour damselfish & microsatellites & 5 & Caribbean Sea & 3020 & $0.003(0.008)$ & Purcell et al. (2009) \\
\hline Syngnathus floridae & Dusky pipefish & microsatellites & 6 & NW Atlantic & 3290 & $0.026(0.054)$ & Mobley et al. (2010) \\
\hline
\end{tabular}

${ }^{a}$ Hawaii, Marquesas and Clipperton samples excluded; b Marquesas sample excluded 
Borsa, P., 2003. Mar. Biol. 142, 575-581.

Borsa, P., Blanquer, A., Berrebi, P., 1997. Mar. Biol. 129, 233-246.

Chevolot, M., Hoarau, G., Rijnsdorp, A.D., Stam, W.T., Olsen, J.L., 2006. Mol. Ecol. 15, 3693-3705.

Dudgeon, C.L., Broderick, D., Ovenden, J.R., 2009. Mol. Ecol. 18, 248-261.

Fauvelot, C., Borsa, P., 2011. Biol. J. Linn. Soc.y 104, 886-902.

Francisco, S.M., Faria, C., Lengkeek, W., Vieira, M.N., Velasco, E.M., Almada, V.C., 2011. J. Exp. Mar. Biol. Ecol. 403, 14-20.

Gaither, M.R., Toonen, R.J., Robertson, D.R., Planes, S., Bowen, B.W., 2010. J. Biogeogr. 37, 133-147.

González-Wangüemert, M., Cánovas, F., Pérez-Ruzafa, A., Marcos, C., Alexandrino, P., 2010. J. Exp. Mar. Biol. Ecol. 383, $23-31$.

Hemmer-Hansen, J., Nielsen, E.E.G., Grønkjær, P., Loeschcke, V., 2007. Mol. Ecol. 16, 3104-3118

Hoarau, G., Rijnsdorp, A.D., van der Veer, H.W., Stam, W.T., Olsen, J.L., 2002. Mol. Ecol. 11, 1165-1176.

Horne, J.B., Momigliano, P., Welch, D.J., Newman, S.J., van Herwerden, L. 2011. Mol. Ecol. 20, 2291-2306.

Jones D.B., Jerry D.R., McCormick, M.I., Bay, L.K., 2010. Coral Reefs 29, 455-467.

Kotoulas, G., Bonhomme, F., Borsa, P., 1995. Mar. Biol. 122, 361-375.

Magsino, R.M., Juinio-Meñez, M.A., 2008. Mar. Biol. 154, 519-532.

Matschiner, M., Hanel, R., Salzburger, W., 2009. Mol. Ecol. 18, 2574-2587.

McCusker, M., Bentzen, P., 2010. Mol. Ecol. 19, 4228-4241.

Mobley, K.B., Small, C.M., Jue, N.K., Jones, A.G., 2010. J. Biogeogr. 37, 1363-1377.

Muths, D., Tessier, E., Gouws, G., Craig, M., Mwale, M., Mwaluma, J., Mwandya, A., Bouriea, J., 2011. Mar. Ecol. Prog. Ser. 443, 167-180.

Ovenden, J.R., Morgan, J.A.T., Street, R., Tobin, A., Simpfendorfer, C., Macbeth, W., Welch, D., 2011. Mar. Biol. 158, 1497-1509.

Planes, S., Fauvelot, C., 2002. Evolution 56, 378-399.

Plank, S.M., Lowe, C.G., Feldheim, K.A., Wilson, R.R., Brusslan, J.A., 2010. J. Fish Biol. 77, 329-340.

Puebla, O., Bermingham, E., Guichard, F., 2009. Ecology 90, 3087-3098.

Purcell, J.F.H., Cowen, R.K., Hughes, C.R., Williams, D.A., 2009. J. Fish Biol. 74, 403-417.

Rohfritsch, A., Borsa, P., 2005. Heredity 95, 315-322.

Roldán, M.I., García-Marín, J.L., Utter, F.M., Pla, C., 1998. Heredity 81, 327-334

Rolland, J.L., Bonhomme, F., Lagardère, F., Hassan, M., Guinand, B., 2007. Mar. Biol. 151, 327-341.

Timm, J., Planes, S., Kochzius, M., 2012. Conserv. Genet. 13, 693-706. 